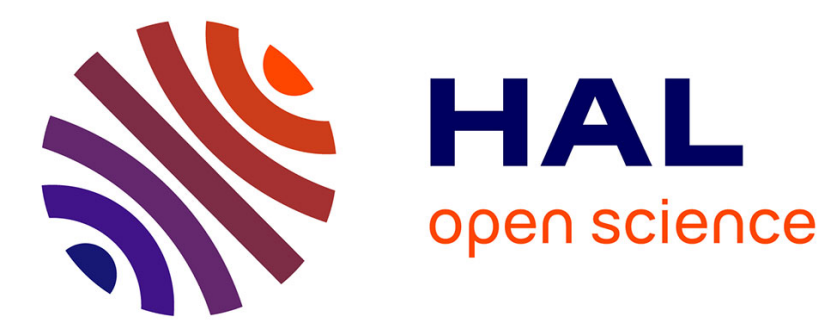

\title{
Clostridial pore-forming toxins: Powerful virulence factors
}

Michel Popoff

\section{To cite this version:}

Michel Popoff. Clostridial pore-forming toxins: Powerful virulence factors. Anaerobe, 2014, 30, pp.220 - 238. 10.1016/j.anaerobe.2014.05.014 . pasteur-01797567

\section{HAL Id: pasteur-01797567}

\section{https://hal-pasteur.archives-ouvertes.fr/pasteur-01797567}

Submitted on 1 Aug 2018

HAL is a multi-disciplinary open access archive for the deposit and dissemination of scientific research documents, whether they are published or not. The documents may come from teaching and research institutions in France or abroad, or from public or private research centers.
L'archive ouverte pluridisciplinaire HAL, est destinée au dépôt et à la diffusion de documents scientifiques de niveau recherche, publiés ou non, émanant des établissements d'enseignement et de recherche français ou étrangers, des laboratoires publics ou privés.

\section{(2)(1) $\$$}

Distributed under a Creative Commons Attribution - NonCommercial - ShareAlikel 4.0 


\section{Elsevier Editorial System(tm) for Anaerobe}

Manuscript Draft

Manuscript Number:

Title: CLOSTRIDIAL PORE-FORMING TOXINS: POWERFUL VIRULENCE FACTORS

Article Type: SI: Clostpath meeting 2013

Section/Category: Pathogenesis \& Toxins

Keywords: Clostridium; toxins; pore-forming toxins; cholesterol-dependent cytolysin, aerolysin; Perfringolysin; Clostridium perfringens epsilon toxin; Clostridium perfringens enterotoxin; Clostridium perfringens beta toxin; Clostridium septicum alpha toxin; Staphylococcus aureus alphahemolysin

Corresponding Author: Dr Michael R Popoff,

Corresponding Author's Institution: Laboratoire des Toxines Microbiennes

First Author: Michael R Popoff

Order of Authors: Michael R Popoff

Abstract: Pore formation is a common mechanism of action for many bacterial toxins. More than one third of clostridial toxins are pore forming toxins (PFTs) belonging to the $\beta$-PFT class. They are secreted as soluble monomers rich in $\beta$-strands, which recognize a specific receptor on target cells and assemble in oligomers, Then, they undergo a conformational change leading to the formation of a $\beta$ barrel, which inserts into the lipid bilayer forming functional pore. According to their structure, clostridial $\beta$-PFTs are divided into several families. Clostridial cholesterol-dependent cytolysins form large pores, which disrupt the plasma membrane integrity. They are potent virulence factors mainly involved in myonecrosis. Clostridial heptameric $\beta$-PFTs (aerolysin family and staphylococcal $\alpha$ hemolysin family) induce small pores which trigger signaling cascades leading to different cell responses according to the cell types and toxins. They are mainly responsible for intestinal diseases, like necrotic enteritis, or systemic diseases/toxic shock from intestinal origin. Clostridial intracellularly active toxins exploit pore formation through the endosomal membrane to translocate the enzymatic component or domain into the cytosol. Single chain protein toxins, like botulinum and tetanus neurotoxins, use hydrophobic $\alpha$-helices to form pores, whereas clostridial binary toxins encompass binding components, which are structurally and functionally related to $\beta$-PFTs, but which have acquired the specific activity to internalize their corresponding enzymatic components. Structural analysis suggests that $\beta$-PFTs and binding components share a common evolutionary origin. 


\section{Highligths}

- Most of clostridial toxins are $\beta$-pore-forming toxins

- Clostridial cholesterol-dependent cytolisins are mainly involved in myonecrosis and gangrene

- heptameric $\beta$-PFTs are divided into aerolysin and staphylococcal alpha hemolysin families 


\title{
CLOSTRIDIAL PORE-FORMING TOXINS: POWERFUL VIRULENCE FACTORS
}

\author{
Popoff Michel R. \\ Institut Pasteur, Unité des Bactéries anaérobies et Toxines, Paris, France \\ mpopoff@pasteur.fr
}

Key words: Clostridium; toxins; pore-forming toxins; cholesterol-dependent cytolysin, aerolysin; Perfringolysin; Clostridium perfringens epsilon toxin; Clostridium perfringens enterotoxin; Clostridium perfringens beta toxin; Clostridium septicum alpha toxin; Staphylococcus aureus alpha-hemolysin 


\section{Abstract}

Pore formation is a common mechanism of action for many bacterial toxins. More than one third of clostridial toxins are pore forming toxins (PFTs) belonging to the $\beta$-PFT class. They are secreted as soluble monomers rich in $\beta$-strands, which recognize a specific receptor on target cells and assemble in oligomers, Then, they undergo a conformational change leading to the formation of a $\beta$-barrel, which inserts into the lipid bilayer forming functional pore. According to their structure, clostridial $\beta$-PFTs are divided into several families. Clostridial cholesterol-dependent cytolysins form large pores, which disrupt the plasma membrane integrity. They are potent virulence factors mainly involved in myonecrosis. Clostridial heptameric $\beta$-PFTs (aerolysin family and staphylococcal $\alpha-$ hemolysin family) induce small pores which trigger signaling cascades leading to different cell responses according to the cell types and toxins. They are mainly responsible for intestinal diseases, like necrotic enteritis, or systemic diseases/toxic shock from intestinal origin. Clostridial intracellularly active toxins exploit pore formation through the endosomal membrane to translocate the enzymatic component or domain into the cytosol. Single chain protein toxins, like botulinum and tetanus neurotoxins, use hydrophobic $\alpha$-helices to form pores, whereas clostridial binary toxins encompass binding components, which are structurally and functionally related to $\beta$-PFTs, but which have acquired the specific activity to internalize their corresponding enzymatic components. Structural analysis suggests that $\beta$ PFTs and binding components share a common evolutionary origin.

\section{1 - Introduction}

Life is organized in cells, which are delineated by a membrane. Cell membrane is not just a physical barrier between the intracellular and external compartments, but it is a complex structure, which has a crucial role for cell life notably in regulating the selective exchanges of molecules and in sensoring external signals. Thereby, cell membrane integrity is required for survival and membrane represents the first target for pathogen attack. Pore formation through a cell membrane resulting in cellular ion imbalance and eventually to cell death is probably the simplest mechanism to attack a target cell. Many proteins including toxins are able to induce a pore through a membrane. It is possibly the reason why pore-forming toxins (PFTs) are the largest class of bacterial protein toxins. Almost one third of bacterial protein toxins, including clostridial toxins, are PFTs [1-4]. PFTs are also produced by all the classes of organisms including mammals, invertebrates, plants, and mushrooms. Indeed, pore formation 
is used by host proteins called membrane-attack complex/perforins (MACPF) in physiological processes like immune defenses or development [5, 6]. PFTs and MACPFs share a common feature consisting of secreted soluble proteins, which interact with the hydrophobic membrane bilayer and form a pore. According to their structure, PFTs can be divided into two main classes the $\alpha$-PFTs and $\beta$-PFTs. Clostridial PFTs belong mainly to the $\beta$-PFT family and are important virulence factors, whereas $\alpha$-pore forming activity is conserved in certain single chain protein toxins produced by clostridia and it is involved in the translocation of the enzymatic domain into the cytosol.

\section{2 - Mechanisms of pore formation}

The two main mechanisms of pore formation are related to the PFT structure. $\alpha$-PFTs are molecules rich in $\alpha$-helices, the pore-forming domain of which commonly contains a bundle of $\alpha$-helices with a hydrophobic helical hairpin in the middle, and which is involved in pore formation through the lipid bilayer. In contrast, $\beta$-PFTs are mainly constituted of $\beta$ sheets and develop a particular structure, which is an amphipatic $\beta$-barrel, to form the pore. PFTs can form either small $(0.5-5 \mathrm{~nm})$ or large $(20-100 \mathrm{~nm})$ pores and the specificity of the pores is variable according to the PFT.

\section{1 - $\alpha$-Pore-forming toxins}

Colicins produced by Escherichia coli are representative of $\alpha$-PFTs. Colicins are proteins which efficiently kill related E. coli strains or closely related bacteria. Some colicins are active through a pore-forming mechanism, others exhibit an enzymatic activity towards RNA, DNA, or peptidoglycan precursors [7, 8]. However, all colicins share a conserved structure consisting of 3 domains rich in $\alpha$-helices including a $\mathrm{N}$-terminal translocation domain involved in the crossing of the outer-membrane, a central receptor-binding domain, and a C-terminal pore-forming or enzymatic domain. Structure of a representative colicin (colicin E3) is shown in Fig. 1A. Colicins translocate through the inner-membrane by various mechanisms, and when in the periplasmic space, pore-forming colicins, like colicin A, insert into the inner membrane [7, 8]. The colicin A pore-forming domain consists of a bundle of 10 $\alpha$-helices where H8-H9 form a hydrophobic helical hairpin (Fig. 1B). The pore-forming domain associates with lipid bilayer by electrostatic attraction, and upon an unfolding process, $\mathrm{H} 8$ and $\mathrm{H} 9$ insert into the bilayer in a perpendicular or nearly parallel manner with respect to the plane of the membrane. A local $\mathrm{pH}$ decrease $(\sim 1.5)$ probably triggers the conformational change allowing the insertion into the membrane and pore formation [9]. This $\alpha$-helical 
structure including a bundle of $\alpha$-helices with a central hidden hydrophobic helical hairpin is also shared by single chain intracellularly active toxins, which use such a translocation domain to deliver the enzymatic domain into the cytosol. For example, diphtheria toxin contains a translocation domain with $9 \alpha$-helices, including helices $\mathrm{H} 8$ and $\mathrm{H} 9$ forming a helical hairpin which inserts into the endosomal membrane leading to pore-formation (Fig. 1C). These helices are probably stabilized by association with a second helical hairpin (helices H5, H6 and H7). Pore formation is required but it is not sufficient for delivery of the catalytic domain across the endosomal membrane. The other helices $\mathrm{H} 1$ to $\mathrm{H} 7$ are also involved in the translocation mechanism which results of multiple insertion intermediates and which is still a matter of debate [10-12].

Another example of $\alpha$-helical PFT is provided by E. coli hemolysin E (HlyE) (also called cytolysin A or silent hemolysin A). HlyE is a $34 \mathrm{kDa}$ long rod shaped molecule formed by a bundle of $4 \alpha$-helices with a helical "tail" subdomain and a "head" subdomain containing a short hydrophobic $\beta$-hairpin, called $\beta$-tongue (Fig. 1D). HlyE is secreted as soluble monomers in a vesicle-mediated pathway. The monomers are activated by cleavage of intramolecular disulfide bonds and then assemble in a dodecameric prepore structure. HlyE undergoes conformational changes including movement and extension of the $\beta$-tongue in hydrophobic $\alpha$-helix. Thereby, each protomer becomes an elongated three-helix bundle. The dodecamer adopts a cone-shaped $\alpha$-helical barrel inside the pore [13-15]. Thus, HlyE is a model of $\alpha$-PFT, which oligomerizes and forms a $\alpha$-barrel which inserts into the target membrane leading to pore formation.

\section{2 - $\beta$-Pore-forming toxins}

$\beta$-PFTs share a common basic mechanism of activity. They are secreted as soluble monomers which diffuse in the extra-bacterial environment and recognize specific receptor(s) on the surface of target cells. Clustering of $\beta$-PFT monomers on cell surface promotes their oligomerization and conformational change of one or two amphipatic $\beta$-sheet(s) from each monomer which assemble and form a $\beta$-barrel, also called the prepore. Insertion of the prepore into the lipid bilayer results in pore formation and subsequent alteration of the membrane permeability (Fig. 2) [16].

According to their structure, clostridial $\beta$-PFTs able to form a pore in plasma membrane can be classified into three families: cholesterol-dependent cytolysin (CDCs), and the heptameric $\beta$-PFTs including the aerolysin family, and the Staphylococcus aureus alpha toxin family (Table 1). In addition, certain clostridial $\beta$-PFTs form pores in the membrane of 
intracellular compartments, thereby facilitating the translocation of the enzymatic domain into the cytosol.

\section{3 - Cholesterol-dependent cytolysins}

The CDC family encompasses toxins, which are produced by numerous Gram positive bacteria such as listeriolysin O of Listeria monocytogenes, pneumolysin of Streptococcus pneumoniae, and streptolysin O (SLO) from Streptococcus pyogenes. Various Clostridia produce CDC (C. botulinum, C. chauvoei, C. perfringens, C. tetani, ...) (Table 1). The members of this toxin family exhibit $40-80 \%$ identity at the primary structure and share common biological properties and structural characteristics $[1,17,18]$.

\section{1 - Perfringolysin}

Perfringolysin $\mathrm{O}$ (PFO) or theta toxin is the prototype of the CDC family. PFO is produced by almost but not all $C$. perfringens strains, and the $p f o$ gene is located on the chromosomal DNA near the origin of replication [19-21]. PFO is synthesized with a 27 amino acid signal peptide, and the mature protein consists of 472 amino acids (53 kDa) [22].

PFO has an unusual elongated rod shape (Fig. 3). The molecule is rich in $\beta$-sheet and it is hydrophilic without significant patches of hydrophobic residues on the surface. Four domains can be distinguished in the PFO molecule. Domain 1 has a seven-stranded antiparallel $\beta$-sheet and is connected to domain 4 by the elongated domain 2 . Domain 3 consists of $\beta$-sheets and $\alpha$-helices. The $\mathrm{C}$-terminal part (domain 4 ) folds into a separate and compact $\beta$-sandwich domain [23], and contains three loops (L1-L3), which are involved in the binding to choleterol [24]. Molecular modeling shows that cholesterol binding to this region induces a displacement of a Trp rich loop. It is proposed that the high affinity $\left(\mathrm{Kd} 10^{-}\right.$ $\left.{ }^{9} \mathrm{M}\right)$ of PFO and also othe CDCs to the cholesterol receptor is involved in concentrating the toxin in cholesterol molecules organized in arcs on the target membrane, thus promoting oligomerization and membrane insertion [23]. Cholesterol is clustered in membrane microdomains enriched in certain lipids (cholesterol, sphingolipids) or rafts, and PFO is a useful tool to identify the membrane rafts [25].

\section{2 - Mode of action}

The proposed model of PFO pore formation includes the binding of water soluble PFO monomers to cholesterol of lipid bilayer mediated by the L1-L3 loops from domain 4 (Fig. 3) [24]. The threonine-leucine pair $\left({ }_{490} \mathrm{TL}_{491}\right)$ located at the top of loop L1 plays an essential role in binding to cholesterol [26]. Binding of domain 4 to its membrane receptor is sufficient to 
trigger an allosteric activation of toxin monomers. Conformational change of domain 4 upon binding to cholesterol induces transition states through the molecule until the distant domains 1 and 3, thus permitting the oligomerization and unfolding of transmembrane hairpins leading to formation of the prepore $[27,28]$. The mechanism of allosteric PFO activation dependent of binding to cholesterol controls monomer interactions and pore formation when the toxin is in closed contact with the cell membrane and avoids formation of premature and nonproductive toxin associations. A conserved undecapeptide motif among CDCs, also known as the Trp-rich loop, located at the tip of the D4 domain, plays a critical role in the allosteric coupling of membrane binding of D4 to structural change of D3 domain [29]. Domain 4 does not insert deeply into the membrane and is not directly involved in creating the pore. PFO monomers bound to cholesterol and orientated perpendicularly to the membrane assemble and oligomerize to form a prepore complex [30]. Oligomers consist of 40 to 50 monomers forming on the membrane surface large arcs and rings. Domains 1, 2 and 4 fit into L-shaped repeating units connected to the corresponding domains of the neighboring partners and forming a cylindrical structure. Oligomer formation results from domain 3-domain-3 interaction via hydrogen bonding between $\beta 1$-strand of one subunit with $\beta 4$-strand of a second subunit. Interaction of domain 4 with cholesterol induces a conformational change of domain 1 causing the moving of $\beta 5$-strand which prevents $\beta 1-\beta 4$ interaction in the soluble PFO form and thus permitting the oligomerization process only when PFO interact with cell membrane [18, 28, 31-34]. Thereby, PFO monomers do not oligomerize in solution even at high concentrations. In addition, domains 3 are rotated from domains 2 and form a belt in the outside face of the cylinder. This is accompanied by a flexing of domain 2 leading to a loss of many contacts between domain 3 and domain 2 thus promoting the exposure of hydrohobic residues and the insertion of a transmembrane $\beta$-barrel into the lipid bilayer $[27,35,36]$. A bundle of three $\alpha$-helices of domain 3 unfolds forming two amphipathic $\beta$-sheets. Each monomer contributes two amphipathic $\beta$-hairpins to the formation of the transmembrane $\beta$ barrel (Fig. 3) [37, 38]. Monomers do not insert their transmembrane hairpins individually, but a cooperation between PFO monomers is required to drive the insertion of the prepore complex, which appears to be an all or none process [39]. The prepore complex remains localized above the lipid bilayer. A vertical collapse of the prepore of $40 \AA$ allows the insertion of the $\beta$-barrel into the membrane and formation of a large membrane pore $300 \AA$ and $450 \AA$ in diameter(Table 2) [40-42]. The charged face of domain 4 amphipathic $\beta$-hairpin 
forms the inner lining of the pore and the other face is protected from the hydrophobic part of the lipid bilayer by cholesterol molecules [23].

Since PFO is more active at low $\mathrm{pH}(5.5-6)$ than neutral $\mathrm{pH}$, PFO can act at the surface of cell membranes which are locally acid due to glycosylated proteins and/or in phagosomes $[27,43]$.

\subsection{Role in the pathogenesis}

Except intermidilysin (ILY) produced by Streptococcus intermedius which binds to CD59 a glycosyl phosphatidylinositol anchored membrane protein, CDCs recognize the cholesterol as cell surface receptor and thus interact with a large number of cell types [18]. CDCs are able to lyse a wide variety of cells in vitro. Notably, CDCs recognize red blood cells and are hemolytic, and they were originally called hemolysins. CDCs experimentally form only large pores (up to $40 \mathrm{~nm}$ in diameter) without possibility of intermediate pores on plasma membrane leading to osmotic lysis. But, it is not excluded that smaller size pores could result from assembly of fewer monomers [2, 18]. However, the CDC-dependent cell lysis in the initial steps of infection is not fully determined.

The main role of pore formation by CDCs seem to allow the release of nutrients from cells and then to facilitate bacterial growth and dissemination.

Pores induced by PFTs could be used by pathogens to internalize virulence factors into target cells in a similar manner than Gram negative bacteria type III to VI secretion systems. This has been evidenced only for Streptococcus pyogenes which uses SLO to transport NAD glycohydrolase, also produced by the pathogen, into cells [44, 45]. The SLO-mediated internalization is specific, since PFO is unable to facilitate the uptake of NAD glycohydrolase [45]. Thereby, translocation of NAD glycohydrolase into keratinocytes leads to apoptosis and cell death, whereas SLO-defective S. pyogenes mutants were less cytotoxic (review in [18]).

CCDs can also form pores in membrane of intracellular compartments. The best example is listeriolysin (LLO), which is produced by the intracellular pathogen, Listeria monocytogenes. LLO preferentially forms pore at acidic $\mathrm{pH}$ (optimal activity at $\mathrm{pH} 5.5$ ) and has an essential role in the L. monocytogenes escape from phagosome allowing the bacterial survival in the cytosol. LLO seems to have a more complex activity than just to induce vacuole membrane disruption at the acidic $\mathrm{pH}$ of phagosomal vacuole. LLO possibly induces the release of bacterial phospholipases into the cytosol and also acts in concert with host factors such as GILT ( $\gamma$-interferon-inducible lysosomal thiol reductase) and CFTR (cystic fibrosis transmembrane conductance regulator) [46, 47]. LLO can form large and small size 
pores, not only in membrane of endosomal compartments but also in plasma membrane. During infection, LLO is produced intracellularly but also extracellularly and thus activates several cell signaling like nuclear factor- $\kappa \mathrm{B}(\mathrm{NF}-\kappa \mathrm{B})$, mitogen-activated protein kinase (MAPK), phosphatidylinositol, and calcium signaling promoting autophagy, inflammasome activation via efflux of $\mathrm{K}^{+}$and caspase 1 activation, stimulation of the innate immune response notably via the Toll Like Receptor 4 (TLR4), mitochondrial fragmentation, modulation of the SUMOylation pathway, and histone modifications. The pleiotropic effects of LLO contribute to the L. monocytogenes infection and escape to the host defense [46, 47].

Clostridial CCDs are mainly involved in gangrene lesions by contributing to tissue destruction and preventing bacterial lysis by host immune cells. It is noteworthy that Clostridia responsible for gangrene produce a CCD and also other membrane damaging toxin(s) such as another PFT or a phospholipase and additional hydrolytic enzymes (Table 1). Thereby, clostridial CCDs act synergistically with other membrane damaging toxin(s) to generate the gangrene lesions. Indeed, using $C$. perfringens mutant strains defective either on PFO or alpha-toxin gene, a synergistic effect between PFO and alpha-toxin has been evidenced in experimental C. perfringens gangrene [48-50].

Among clostridial CCDs, PFO is the most well characterized regarding its mode of activity. PFO by forming large pores on plasma membrane induces a cell lysis by a colloid osmotic mechanism [51]. Albeit PFO can induce or interfere with cell signalings like the SUMOylation pathway [52], its main activity resides in alteration of the membrane integrity. A hallmark of clostridial gangrene lesions caused by C. perfringens and other clostridia, is the total absence of inflammatory cells at the site of infection. At high concentration, PFO is cytotoxic for polymorphonuclear lymphocytes (PMNL) and macrophages. At lower concentrations, PFO impairs respiratory burst, superoxide anion production, and phagocytosis of complement opsonized particles in PMNL $[53,54]$. In addition, C. perfringens can survive in macrophages, and PFO has a major role in the escape of the bacteria from phagosome by lysis of the endosome membrane and in macrophage cytotoxicity $[55,56]$.

At the periphery of the necrotic lesions, PFO at sublethal concentrations reduces the migration of PMNL/macrophages and induces their adherence to endothelial cells (Fig. 4). PFO upregulates the expression/activation of adherence molecules such as neutrophil $\mathrm{CD} 11 \mathrm{~b} / \mathrm{CD} 18$, endothelial adherence molecules, platelet activating factor (PAF) and subsequent phospholipase A2 synthesis [53, 57, 58]. Moreover, PFO prevents actin filament polymerization in leucocyte and migration of neutrophils in response to chemoattractant [53, 54]. Accumulation of PMNL and macrophages in the vessels around the site of infection and 
inhibition of their migration mostly contribute to the lack of inflammatory response. In addition, PFO synergistically with $C$. perfringens alpha toxin triggers platelet/platelet and platelet/leucocyte aggregation through activation of the platelet fibrinogen receptor gpIIb/IIIa $[59,60]$. PFO also stimulates the expression of intercellular adherence molecule 1 (ICAM-1) in endothelial cells, but to a much lesser extent than $C$. perfringens alpha toxin [57]. These events result in the formation of intravascular platelet/leucocyte/fibrin aggregates leading to vessel obstruction, hypoxia, and tissue destruction. Indeed the blood flow is reduced in the microvasculature of the infected tissues [61, 62]. Adherence of the aggregates to the vascular endothelial cells leads to vascular injury and subsequently contributes to the impairment of leucocyte migration by diapedesis and tissue hypoxia [63-65].

The late stage of clostridial gangrene is characterized by cardiovascular collapse, tachycardia, low blood pressure, and multiorgan failure (Fig. 4). Toxins, like PFO and alpha toxin, are released in the blood circulation and act at distance of the site of infection on the cardiovascular system. Notably, PFO reduces the systemic vascular resistance and increases the cardiac output, decreases heart rate without drop in mean arterial pressure $[66,67]$. PFO contributes also indirectly to the toxic shock (hypotension, hypoxia, reduced cardiac output) by promoting the release of inflammatory interleukins (TNF, IL1, IL6, PAF, and prostaglandin $\mathrm{I}_{2}$ ) and by acting synergistically with $C$. perfringens alpha toxin $[65,68]$.

The role in pathogenesis of botulinolysin and tetanolysin which are not associated with other cytotoxins in $C$. botulinum and $C$. tetani, respectively, remains to be determined. These CDCs could facilitate the local tissue colonization and resistance to macrophages of $C$. botulinum and $C$. tetani during the early steps of wound botulism and tetanus, respectively. Indeed, tetanolysin is able to form pores and to induce membrane damages in macrophages [69]. In addition, botulinolysin is active on vascular endothelium leading to vasoconstriction, hypotension and heart dysfunction in experimental rats. This seems to be a common activity of CDCs, since SLO has also been found to be cardiotoxic [70, 71]. However, the effect of botulinolysin on the cardio-respiratory system in the natural disease is not known.

\section{4 - Clostridial heptameric $\beta$-Pore-forming toxins}

An important group of clostridial $\beta$-PFTs is that of the heptameric $\beta$-PFTs. In contrast to CDCs, they associate in smaller oligomers, heptamers or to a lower extent hexamers or octamers, leading to the formation of small pores into membrane (Table 2) [72]. Whereas all CDCs recognize a unique cell surface receptor, which is the cholesterol, except 
intermedilysin, heptameric $\beta$-PFTs bind to distinct receptor(s). Thereby, they are active on different subsets of cell types and they are responsible for specific diseases. Clostridial heptameric $\beta$-PFTs are mainly involved in intestinal diseases rather than in myonecrosis like clostridial CDCs (Table 1). Most of them are produced by C. perfringens.

Based on their structure, clostridial heptameric $\beta$-PFTs are divided into two families: the aerolysin family and the Staphylocccus aureus alpha hemolysin family.

\section{1 - Aerolysin family}

C. perfringens epsilon toxin (ETX), C. perfringens enterotoxin (CPE), and $C$. septicum alpha-toxin (ATX) are structurally related to aerolysin produced by Gram-negative bacteria of Aeromonas sp., although ETX and CPE show no significant homology with aerolysin at the amino acid level (Fig. 5) [73-77]. ATX shares a low level (27\%) of amino acid sequence identity with aerolysin [78]. The $\beta$-PFT aerolysin family also contains toxins from diverse origin, bacteria, animal, plant, like mosquitocidal toxins toxins (Mtxs) from the Gram-positive bacteria Bacillus sphaericus, hydralysins from the animal Chlorohydra viridis, enterolobin from the Brazilian tree Enterolobium contortisiliquum, Laetiporus sulphurous lectin (LSL) from the mushroom Laetiporus sulphurous, and lysenin from the eartworm Eisenia fetida (review in [79-81]). Aerolysin has been extensively analyzed and is the prototype of this toxin family [82].

Aerolysin and clostridial $\beta$-PFTs of the aerolysin family are secreted through a Nterminal signal peptide as prototoxin monomers, except CPE which contains no signal peptide and accumulate in sporulating bacterial cells [83]. Aerolysin is converted into mature toxin by proteoltytically removing of a C-terminal peptide (38 to 43 amino acids) by bacterial or host eukaryotic proteases [82]. Similarly, clostridial $\beta$-PFTs of the aerolysin family are released as inactive monomers. ETX is activated by cutting of 11 to $13 \mathrm{~N}$-terminal and $29 \mathrm{C}$-terminal residues [84], and ATX processing results from the cleavage of $45 \mathrm{C}$-terminal amino acids [85]. ETX is mainly activated in solution by $C$. perfringens $\lambda$-protease or proteases of the host digestive tract, and ATX is mainly cleaved by furin, a cell surface associated protease [85]. CPE has also been found to be activated by trypsin or chymotrypsin which removes 24 or 36 N-terminal amino acids, respectively Kokai'-Kun, 1997 \#560]. As shown in ATX, the propeptide acts as an intramolecular chaperone, which stabilizes monomers in solution, prevents unproductive aggregates, and drives correct oligomerization when the toxin is bound to membrane [86]. 


\subsection{1 - Structure of aerolysin family $\beta$-PFTs}

$\beta$-PFTs from the aerolysin family exhibit a more elongated shape than PFO (Fig. 2). They consist of 3 to 4 domains and associate mainly in heptamers. The domain interacting with the receptor is the $\mathrm{N}$-terminal domain 1, except in CPE, in which, like in PFO, it is the C-terminal domain. $\beta$-PFTs of aerolysin family recognize GPI-anchored proteins or membrane proteins as receptors instead of lipids which are receptors of CDCs and some $\beta$ PFTs of the $\alpha$-hemolysin family (see below). A hallmark of heptameric PFTs is that each monomer deploys only one $\beta$-hairpin forming the transmembrane $\beta$-barrel $[80,82,87]$.

Aerolysin is a L-shaped molecule rich in $\beta$-structure with a small $\mathrm{N}$-teminal lobe (domain 1) and a big elongated lobe spilled in three more domains (2 to 4) with the characteristic feature of the presence of long $\beta$-strands (Fig. 5). Domains 1 and 2 are involved in the recognition of GPI-anchored proteins through a double binding mechanism leading to high affinity interaction of aerolysin with its receptor. Domain 1 binds to N-linked sugar of the protein part of GPI-anchored proteins and domain 2 to the glycan core. Domain 2 with domain 3 are involved in the oligomerization process. Domain 4 is located on the tip of the major lobe and contains the C-terminal peptide which is released upon proteolytic cleavage. Removing of the propeptide probably induces a conformational change and reorganization of the domains which facilitate the formation of oligomers [2, 80, 82].

The structures of ETX and CPE have been solved and show a similar fold than that of aerolysin despite no significant amino acid sequence homology (Fig. 5). The main difference is the absence of aerolysin domain 1. ETX and CPE retain an elongated shape with three domains $[73,75,88]$. ATX probably shares a similar structure than aerolysin based on related (27\%) amino acid sequence identity [76-78]. Like ETX and CPE, ATX lacks the aerolysin domain 1. Similarly to aerolysin, domains 1 of ETX and ATX are involved in the interaction with the receptor $[77,89]$, whereas the CPE binding domain to receptor is located on the Cterminal domain $3[73,75]$. ATX recognizes GPI-anchored proteins as receptors, which are different from those interacting with aerolysin, except Thy- 1 and contactin, two common receptors for both toxins [90]. CPE binds to claudins, which are membrane proteins involved in intercellular junctions [91, 92], and the membrane protein HAVCR1 (hepatitis A virus cellular receptor 1) has been proposed as the receptor for ETX [93]. Domains 2 and 3 of ETX and ATX are involved in oligomerization and maintenance of the oligomers.

The domain 3 of aerolysin and domains 2 of ETX, ATX, and CPE, contain the membrane spanning $\beta$-hairpin. In aerolysin, the transmembrane region consists of 20 amino 
acids forming two amphipatic $\beta$-sheets connected by a hydrophobic 5 amino acid long stretch

which folds in an amphipatic $\beta$-hairpin upon olgomerization and membrane insertion. The hydrophobic turn of the $\beta$-hairpin is thought to drive membrane insertion and folds back after membrane crossing in a rivet-like fashion, thereby anchoring the $\beta$-barrel in the membrane [94]. A similar structure is conserved with some differences in the clostridial $\beta$-PFTs of the aerolysin family. In soluble CPE monomer, the transmembrane region folds in a helix and $\beta$ strand $[73,75]$. Hydrophobic residues also lie in the interconnection between the two amphipatic $\beta$-strands in ETX, ATX and CPE.

\subsection{2 - Mode of action}

The first step of $\beta$-PFTs of the aerolysin family as for the other PFTs is the binding to cell surface receptor. This step has been further analyzed with ETX and ATX labeled with photostable nanoparticle (Europiun). Toxin monomers bound to their receptor are mobile on the cell surface, but in confined areas corresponding to lipids rafts [95]. Indeed, ETX and ATX receptors are localized in lipid rafts $[90,96,97]$. The confinement seems to be mainly due to the composition and spatial organization of the lipids around the proteins and subsequent molecular interactions (local electrostatic interactions, hydrophobic interactions, lipid-protein specific and/or non-specific interactions) in the lipid rafts. Thereby, membrane depletion in cholesterol or sphingolipids results in the release of confinement, and ETX and ATX bound to their receptors move in a wider area. The actin and microtubule cytoskeleton is not directly involved in the ETX and ATX mobility [98, 99]. However, albeit the toxin receptors are not directly linked to actin filaments, other lipid raft proteins are connected to the actin cytoskeleton which mediates the displacement of the whole lipid rafts in the membrane [100]. Mobility of toxin monomers bound to their receptors in confined areas leads to a concentration of toxin molecules and facilitates their interactions and subsequent oligomerisation.

Pore formation has been solved at the structural level with aerolysin. Aerolysin heptamer adopts a mushroom shape similar to that of $\alpha$-hemolysin (see below). However, in contrast to $\alpha$-hemolysin, aerolysin heptamer associates with the membrane in an inverse orientation, the mushroom cap facing the membrane and the stalk in the extracellular milieu, since domains 1 and 2 which binds to the receptor are located in the cap. Then, the heptamer undergoes a vertical collapse. Domain 3 and 4 rotate and completely flatten, and the $\beta$-hairpin from domain 3 moves through a cavity between 
two monomers. The $\beta$-hairpins of the seven monomers refold in a $\beta$-barrel which lies in the opposite orientation to that of the prepore mushroom stalk and which inserts into the membrane (Fig. 5A) [101]. In contrast, CDCs and $\alpha$-hemolysin show no drastic conformational change during the prepore to pore conversion.

ETX and ATX are cytotoxic for sensitive cells and induce a rapid and drastic decrease in cell monolayer integrity. Both toxins seem to share a similar mechanism of cytotoxicity, which has been investigated in more details with ETX [97, 102-104]. The cytotoxicity is associated with a rapid loss of intracellular $\mathrm{K}^{+}$, and an increase in $\mathrm{Cl}^{-}$and $\mathrm{Na}^{+}$, whereas the increase in $\mathrm{Ca}^{++}$occurs later. In addition, the loss of viability also correlates with the entry of propidium iodide, indicating that the epsilon-toxin forms pores in cell membrane. ETX causes a rapid cell death by necrosis characterized by a marked reduction in nucleus size without DNA fragmentation. Toxin-dependent cell signaling leading to cell necrosis is not yet fully understood and includes ATP depletion, AMP-activated protein kinase stimulation, mitochondrial membrane permeabilization, and mitochondrial-nuclear translocation of apoptosis-inducing factor, which is a potent caspase-independent cell death factor. The early and rapid loss of intracellular $\mathrm{K}^{+}$induced by ETX and ATX, seems to be the early event leading to cell necrosis [105] (review in [106-108]. Change in cell membrane permeability with $\mathrm{K}^{+}, \mathrm{Ca}^{++}$, and ATP as the main signaling molecules is a common feature of PFTs [109]. Cellular responses might differ between the distinct PFTs according to their pore selectivity and to their specific receptor. Indeed, in addition to target certain epithelial and endothelial cells, ETX has a specific activity on the nervous system. ETX is able to cross the blood brain barrier and to interact with specific neuronal cells leading to an increased release of glutamate, an excitatory neurotransmitter. But the mechanism of the stimulation of glutamate release is not yet fully understood. Instead of a direct ETX effect on glutamatergic neuronal cells through pore formation, rise in intracellular $\mathrm{Ca}^{++}$and subsequent signaling leading to stimulation of vesicular exocytosis, ETX could induce a neuron depolarization following pore formation. ETX also targets oligodendrocytes which are involved in the myelination process, and thus could have a demyelinating effect $[106,108,110]$

$\mathrm{CPE}$ binds to certain claudin isoforms which are tight junction proteins and have an essential role in the integrity of epithelial barrier such as the intestinal barrier. When bound to cell membrane, CPE forms small complexes (90-100 kDa) and then large complexes (160$200 \mathrm{kDa}$ ) by association with a membrane protein, possibly occludin, which is also a tight junction component. CPE induces cell death by a mechanism not yet well understood. At high 
concentration, CPE seems to trigger cell necrosis, and at low concentration cell apoptosis subsequently to $\mathrm{Ca}^{++}$entry into cells $[83,92,111]$.

\subsection{3 - Role in the pathogenesis}

Clostridial $\beta$-PFTs of the aerolysin family are responsible for mid to severe intestinal diseases or diseases from intestinal origin. The most potent toxin of this family is ETX, the lethality of which in experimental animals ranges just below the botulinum neurotoxins. The ETX lethal dose in mice upon intraperitoneal injection is $70 \mathrm{ng} / \mathrm{kg}$. ETX is the major virulence factor of $C$. perfringens types $\mathrm{B}$ and $\mathrm{D}$, and is responsible for enterotoxemia in sheep, goat and more rarely in cattle. Enterotoxemia is a rapidly fatal disease which causes important economical losses through the world.. Overgrowth of $C$. perfringens type D in the intestine of susceptible animals, generally as a consequence of overeating of food containing a large proportion of starch or sugars, produce large amounts of ETX. The toxin is absorbed through the intestinal mucosa and spreads in the different organs by the blood circulation causing blood pressure elevation, vascular permeability increase, lung edema and kidney alteration (pulpy kidney disease in lambs characterized by a post-mortem kidney softening). The terminal phase of enterotoxemia is characterized by neurological disorders (opisthotonus, convulsions, agonal struggling). ETX increases the permeability of the brain vasculature leading to perivascular edema and stimulates the release of glutamate (review in $[106,107]$. ETX seems not to be involved in natural disease in humans since only a few cases have been described (review in [106]. However, ETX has been recently reported to be a potential virulence factor causing demyelination such as in multiple sclerosis [112].

ATX is involved in gas gangrene and also in non-traumatic myonecrosis of the intestinal mucosa, which occurs in patients with intestinal malignancy, neutropenia, leukemia or diarrhea. This infection is accompanied by a profound shock and it is fulminant and often fatal. The precise mode of action of ATX in these pathologies is no well understood. ATX might target vascular endothelial cells, which could result in the extravasation of fluid from the circulatory system and subsequent shock [113]. In animals, C. septicum is responsible for gangrene, enterotoxemia, and necrotizing abomasitis (braxy or bradsot) [76, 114].

$\mathrm{CPE}$ is one of the most common causative agent of food poisoning in humans. Most of the $C$. perfringens ingested with food die upon exposure to the stomach acidity. But, when ingested in high number, some bacteria can pass into the small intestine. Food involved in $C$. perfringens food poisoning contains at least $10^{5}$ enterotoxigenic $C$. perfringens $/ \mathrm{g}$. Then, $C$. 
perfringens multiply rapidly in the intestine and sporulate. Sporulation is a prerequisite step for $\mathrm{CPE}$ production [4]. $\mathrm{CPE}$ accumulates in the intestine resulting in alteration of the integrity of the intestinal epithelial barrier, desquamation of the intestinal epithelium, and diarrhea. High CPE doses cause enterocyte necrosis, inflammation, diarrhea, and abdominal pain.

Enterotoxigenic $C$. perfringens are also involved in hospital- and community-acquired antibiotic associated diarrhea, in chronic non-food borne diarrhea, and have been suspected in infant death syndrome in humans [115-119] [120, 121], as well as in diarrhea in foals and piglets [122].

\section{2 - $\alpha$-hemolysin family}

C. perfringens delta toxin and NetB toxin constitute a $\beta$-PFT family structurally related to staphylococcal $\beta$-PFTs, the prototype of which is the staphylococcal $\alpha$-hemolysin (or $\alpha$-toxin) (Fig. 6) [123-126]. Albeit containing three domains, the $\beta$-PFTs of the $\alpha$ hemolysin family show a more globular structure than the $\beta$-PFTs of the aerolysin family with a pore forming domain packed against domain I (Fig. 6). Contrarily to $\beta$-PFTs of the aerolysin family, $\beta$-PFTs of the $\alpha$-hemolysin family are not activated by trypsin or other proteases. In contrast, they are sensitive to proteolytic degradation, notably beta and beta2 toxins.

\subsection{1 - Structure of $\alpha$-hemolysin family $\beta$-PFTs}

Staphylococcal $\alpha$-hemolysin is a $33 \mathrm{kDa}$ protein secreted via a 26 amino-acid signal peptide. The protein is water-soluble and does not undergo further proteolytic cleavage. $\alpha-$ Hemolysin is organized in three structural domains: a $N$-terminal $\beta$-sandwich domain formed of two six stranded anti-parallel $\beta$-sheets, a C-terminal rim domain that is rich in $\beta$-strands, and a central domain called a stem (Fig. 6). A hallmark of $\alpha$-hemolysin and related $\beta$-PFTs is that the central stem domain of monomers contains three short $\beta$-strands packed against the $\beta$-sandwich domain [127-130]. C. perfringens delta toxin (32.6 kDa) and NetB (33 kDa) secreted monomers share similar size and structure compared to $\alpha$-hemolysin. They are also organized in three domains, $\beta$-sandwich, rim and stem domains. In addition, the heptameric assembly of NetB retains a similar conformation than that of $\alpha$-hemolysin prepore [123]. However, the rim domain of delta toxin and NetB exhibit significant sequence and conformation differences with that of $\alpha$-hemolysin [123-125]. Since the $\alpha$-hemolysin rim domain is involved in the binding to cell surface receptor(s), these rim differences support that delta toxin and NetB recognize distinct receptors. Indeed, $\alpha$-hemolysin interacts with a 
protein receptor (see below) and delta toxin uses the ganglioside $\mathrm{GM}_{2}$ as receptor $[126,131]$.

NetB receptor is still unknown but could be membrane cholesterol [123].

This family also includes $C$. perfringens beta toxin, which shares significant amino acid sequence homology with delta toxin and staphylococcal $\beta$-PFTs and likely related structure [132]. Beta2-toxin, which has been identified from a C. perfringens strain isolated from a piglet that died of necrotic enteritis, shows no significant amino acid sequence homology with beta toxin or other $\beta$-PFTs [133]. In contrast to beta toxin, beta2 toxin exhibits sequence and expression variations. Two main alleles, termed consensus and atypical cpb2, have been described. Consensus beta2 is mainly found in porcine $C$. perfringens isolates, whereas atypical beta2 is more prevalent in non-porcine isolates [134]. Since beta and beta 2 toxins have in common a similar size, highly sensitivity to trypsin degradation, activity limited to some cell types, and potency to induce experimental necrotic enteritis, beta 2 toxin is likely structurally related to $\beta-$ PFTs of the staphylococcal $\alpha$-hemolysin.

\subsection{2 - Mode of action}

The mode of pore formation through a lipid bilayer has been investigated at the structural level with staphylococcal $\alpha$-hemolysin. Based on their structural relatedness with $\alpha-$ haemolysin, clostridial $\beta$-PFTs likely retain the same mode of activity.

The first step of intoxication consists of the binding of $\alpha$-hemolysin monomer to specific receptor(s) on the cell surface. Phospholipids and cholesterol were initially identified as high affinity receptors for $\alpha$-hemolysin but it was evidenced that the membrane protein, ADAM10 (A disintegrin and metalloprotease 10), is the specific receptor $[135,136]$. When bound to its cell surface receptor via the rim domain, $\alpha$-hemolysin units oligomerize into a heptameric (or hexameric) pre-pore. Upon heptamerization (or hexamerization), the stem $\beta$ strands unfolds and moves from the $\beta$-sandwich to form a $\beta$-hairpin. The $\beta$-hairpin of the stem domains associate into a 14-strand antiparallel $\beta$-barrel that inserts into the plasma membrane and forms the transmembrane pore (Fig. 6). The pore has a mushroom shape with an inner diameter ranging from 22 to $30 \AA$. Overall, $\alpha$-hemolysin and related toxins share a similar mechanism of pore formation than CDCs, except that they form small pores resulting from oligomerization of 6-7 units instead of 30-50 in CDCs, and that each monomer contribute for one hairpin to form the $\beta$-barrel instead of two in CDCs $[128,129,137]$.

The primary activity of $\beta$-PFTs forming small pores on cell membrane is a disruption of the membrane permeability to small molecules leading notably to $\mathrm{K}^{+}$, ATP efflux and 
influx of $\mathrm{Ca}^{++}$, and subsequent deregulation of mitochondrial activity, activation of caspase 1 , release of proinflammatory proteins. At high concentrations, $\beta$-PFTs generally kill cells by necrosis resulting in particular from mitochondria dysfunction, and at lower concentrations they induce cell death via programed necrosis or apoptosis [138]. At sublethal doses they can induce multiple effects on cells including membrane repair, changes in metabolism, activation of signaling pathways like activation of the p38 MAPK pathway, activation of caspases leading to inflammasome activation and released of inflammatory molecules $[128,129]$. In addition, $\alpha$-hemolysin activates the ADAM10 receptor with subsequent cleavage of Ecadherin and decreased endothelial barrier integrity, which facilitates pathogen dissemination in the host [139].

The mode of action of the clostridial $\beta$-PFTs from the $\alpha$-hemolysin family is likely related to that of $\alpha$-hemolysin, notably regarding the effects due to the formation of small pores. Thereby, Beta-toxin associates with human umbilical vein endothelial cell membranes in multimeric complexes [140], and forms cation selective channels in artificial phospholipids bilayers [141]. Beta-toxin pore formation has also been evidenced in phosphatidyl cholinecholesterol liposomes [142]. Beta-toxin induces swelling and lysis of the lymphocytic HL60 cell line, which are preceded by toxin oligomer formation (hexamer or heptamer) in membrane lipid rafts, $\mathrm{K}^{+}$efflux, and $\mathrm{Ca}^{++}, \mathrm{Na}^{+}$, and $\mathrm{Cl}^{-}$influxes [143, 144]. The betadependent $\mathrm{K}^{+}$loss in HL60 was found to trigger the activation of the p38 and JNK MAPK pathways which could have a protective effect of host cell [145]. When injected intradermally, Beta-toxin induces oedema and dermonecrosis, which seem to be mediated by stimulation of sensory nerves containing tachykinins such as substance $\mathrm{P}$ and release of tumor necrosis factor alpha $(\mathrm{TNF} \square)[143,144]$.

\subsection{3 - Role in the pathogenesis}

The clostridial heptameric $\beta$-PFTs of the $\alpha$-hemolysin family are mainly involved in intestinal diseases like necrotic enteritis (Table 1), while staphylococcal $\alpha$-hemolysin causes necrosis and abscesses in various organs. The role of beta toxin in the pathogenesis has been established several decades ago, whereas NetB is a recently identified virulence factor in necrotic enteritis in birds. In contrast, the involvement of delta toxin in natural disease is still poorly understood. Delta toxin might have a synergistic effect with beta toxin, since both toxins are produced together by certain C. perfringens type C strains [126]. 
Beta-toxin is responsible for necrotic enteritis in young animals and in humans (Pigbel and Darmbrand), and in sheep enterotoxemia. Enteritis due to Beta-toxin are characterized by necrosis and inflammation of the intestinal mucosa with bleeding to the lumen [146]. Betatoxin is very labile and sensitive to protease degradation. For this reason, the Beta-induced pathology is only observed in particular circumstances such as in newborns in which the protease activity of the digestive tract is low. The risk factors involved in human disease are low-protein diet inducing low trypsin activity in the intestine and consumption of sweet potatoes, which contain a trypsin inhibitor. The low-protease activity permits a high level of active toxin into the intestinal lumen.

The exact mode of action of beta toxin in the genesis of enteric necrotic lesions is not yet fully understood. Which are the intestinal target cells of beta toxin? In naturally occurring cases of necrotic enteritis in piglets and in on human patient, beta toxin has been found to bind to vascular endothelial cells in the intestinal mucosa. It is speculated that beta toxin binding to endothelial cells is an early event which subsequently induces vascular necrosis and then alteration of the intestinal mucosa [147-149]. In primary human and porcine endothelial cells, beta toxin causes the loss of the actin cytoskeleton and cell death, thus promoting alteration of the integrity of endothelial cell monolayer in vitro $[150,151]$. Beta toxin forms pores in endothelial cell membranes leading to release of $\mathrm{K}^{+}$and ATP, increase in cytosolic $\mathrm{Ca}^{++}$, and then cell death by programmed necrosis subsequently to activation of a non yet defined cell signaling pathway [152]. It remains to elucidate how beta toxin reaches the vascular endothelial cells in the intestinal mucosa from the intestinal lumen, whether the vascular endothelial cells are the only intestinal target cells, and which are the cell surface receptor(s) and the exact mode of cytotoxicity.

According to epidemiological data, consensus beta2-toxin strains are mainly involved in piglet necrotic enteritis and in horse typhlocolitis, whereas atypical beta2 strains have a broader animal species distribution and its pathogenicity remains to be defined [153-158]. Interestingly, the $c p b 2$ gene of $C$. perfringens strains isolated from horses differs from that of strains from pigs by an adenine deletion downstream of the start codon resulting in a premature stop codon after only nine amino acid codons. Therefore, the equine strains do not produce beta2 (92\% identity with consensus beta2) under standard culture conditions [159, 160]. However, antibiotics of the aminoglycoside family such as gentamycin and streptomycin are able to induce expression of $c p b 2$ through a frameshift process.

Beta2-toxin has been immunohistochemically localized in the intestinal wall of diseased horses [161] indicating that this toxin is directly implicated in the genesis of lesions. 
The involvement of beta2-toxin in intestinal diseases in other animal species and humans is still discussed [158, 162-165]. Beta2 toxin might be an additional virulence factor in $C$. perfringens associated diarrhea in human $[163,164]$.

Necrotic enteritis in chickens is an important economical disease in poultry industry. This disease was associated to $C$. perfringens, but the toxin and virulence factors responsible for the lesions remain controversial until the discovery of the new toxin NetB. Evidence that NetB is the main virulence factor involved in necrotic enteritis is based on: (i) a $C$. perfringens netB null mutant failed to cause experimental intestinal necrotic lesions, but was as virulent as the wild type strain when complemented with the netB gene [166], (ii) NetB is cytotoxic for a chicken epithelial cell line in vitro [166], (iii) most of strains isolated from necrotic enteritis outbreaks contain netB gene and non-necrotic enteritis derived isolates lack this gene [166-171], and (iv) only the netB positive isolate from a naturally occurring outbreak was able to reproduce experimental lesions [172].

\section{5 - Clostridial intracellularly active toxins and pore formation}

Pore formation is not directly involved in the mode of action of intracellularly active toxins, but it is an essential step in the mechanism of translocation of the enzymatic component or enzymatic domain from the endosome to the cytosol, where they recognize and modify a specific intracellular target. Two main groups of intracellularly active toxins can be distinguished on the basis of their structure: the single chain protein toxins and the binary or multiple component toxins. Toxins of the two groups use distinct mode of pore formation: the single chain protein toxins form $\alpha$-pores, whereas binary toxins exploit $\beta$-pores.

\section{1 - Pore-forming domains of clostridial intracellularly active toxins}

Clostridial neurotoxins and large clostridial glucosylating (LCGT) toxins are single chain protein toxins, which enter target cells through a receptor-mediated endocytosis and deliver through the endosomal membrane an enzymatic domain into the cytosol.

Clostridial neurotoxins, including botulinum neurotoxins (BoNTs) and tetanus neurotoxin (TeNT), retain a conserved overall structure consisting of three main domains: a C-terminal receptor binding domain (half $\mathrm{C}$-terminal heavy $(\mathrm{H})$ chain), a central translocation domain (half N-terminal $\mathrm{H}$ chain), and a N-terminal enzymatic domain (light (L) chain). The translocation domain (TD) contains two unusually long twisted $\alpha$-helices, which are reminiscent of $\alpha$-helical hairpin of some colicins or viral fusion proteins (Fig. 7A) (review in 
[173]. At the acidic $\mathrm{pH}$ of endosome ( $\mathrm{pH}$ 5.3), TD inserts into the endosomal membrane and forms small conductance channels (20-40 pS and estimated inner diameter of $15 \AA)$. The mode of passage of the $\mathrm{L}$ chain through the endosomal membrane remains unclear. The unfold $\mathrm{L}$ chain at acidic $\mathrm{pH}$ seems not to be able to pass through these small channels, unless several TDs cooperate to form larger channels. The fact that during the L chain translocation, the $\mathrm{Na}^{+}$conductance progressively increases, supports a passage through the TD channels. Another possibility is a chaperone activity between TD and L chain including a partial structure rearrangement (molten globule state) facilitating the exposition of hydrophobic helices and their subsequent insertion into the membrane. However, no conformational change of TD has been detected [173-176].

LCGTs contain a central hydrophobic domain (amino acids 956-1128 in C. difficile toxin $\mathrm{B}$ ), which is involved in pore formation at acidic $\mathrm{pH}$. However, it is not yet established that the translocation of the catalytic N-terminal domain (amino acids 1-543) exploits the LCGT channels [177-179]. LCGTs might use a similar mechanism of translocation than that of clostridial neurotoxins.

\section{2 - Binding components of clostridial binary toxins}

Binary toxins consist of two independent proteins including an enzymatic component and a binding component (BC), which are encoded by distinct, yet adjacent, genes. BCs of clostridial binary toxins (C. perfringens iota toxin, $C$. botulinum $\mathrm{C} 2$ toxin, $C$. difficile transferase (CDT), and Clostridium spiroforme toxin) share a similar structural organization to that of Bacillus anthrax toxins (protective antigen, PA) and Bacillus vegetative insecticidal protein 1 (VIP1) [4, 180, 181]. The structures of clostridial and Bacillus BCs are reminiscent of that of CDCs (Fig. 7B). Indeed, PA which is the prototype of BCs, consists in 4 domains rich in $\beta$-strands highly related to those of PFO (Fig. 7B and 7C). The N-terminal domain 1 contains the binding sites for the enzymatic components, and the C-terminal domain 4 is involved in the recognition of the cell surface receptor. Domain 2 contains a long $\beta$-hairpin, which assembles with adjacent $\beta$-hairpins in the oligomeric structure to form the $\beta$-barrel. No specific function has been attributed to domain 3, which is the smallest one [182, 183]. However, BCs share functional similarities with $\beta$-PFTs of the aerolysin family. Thereby, $\mathrm{BCs}$ are proteolytic activated by removing a N-terminal propeptide. But, the $\mathrm{BC}$ cleaved propeptide is much more longer $(20 \mathrm{kDa})$ than those of aerolysin family $\beta$-PFTs. In addition, in contrast to CDCs and like aerolysin family $\beta$-PFTs, BCs use only one amphipatic $\beta$-hairpin 
from each monomer to built the $\beta$-barrel and form heptamers instead of large oligomers.

Furthermore, $\mathrm{BC}$ amphipatic $\beta$-hairpin share significant amino acid sequence with the corresponding sequences of aerolysin family $\beta$-PFTs. For example the $\beta$-hairpin of $\mathrm{Ib}$ (BC of iota toxin) shows $45 \%$ identity with that of ETX.

\section{3 - Role in the pathogenesis}

Pore formation of the intracellularly active toxins is not directly involved in the mechanism of pathogenesis. But, it is a prerequisite step allowing the internalization of the enzymatic component or domain. BCs form no functional or only weakly active pores in the plasma membrane. BCs drive the translocation of the corresponding enzymatic component or domain at the acidic endosomal $\mathrm{pH}$ through the endosome membrane.

Clostridial neurotoxins are responsible for severe neurological diseases: botulism and tetanus $[173,184,185]$.

LCGTs produced by $C$. difficile (Toxin A and Toxin B) are the main etiological virulence factors of pseudomembranous colitis and about $30 \%$ of the postantibiotic diarrhea, which are the most frequent nosocomial intestinal diseases [186]. LCGTs of $C$. sordellii and C. novyi are involved in gangrene, and C. sordellii is also an agent of hemorrhagic enteritis and enterotoxemia in cattle [187-194].

Clostridial binary toxins are involved in necrotizing enteritis and diarrhea in animals and occasionally in humans. Iota toxin from $C$. perfringens $\mathrm{E}$ causes enterotoxemia in calves and other young animals. C. spiroforme is responsible for enteritis and death in rabbits and rarely in humans. C. botulinum C2 toxin induces intestinal hemorrhagic lesions in avian [4, 181]. CDT from epidemic $C$. difficile strains is considered as an additional virulence factor in pseudomembranous colitis and recurrent post-antibiotic diarrhea [195].

\section{6 - Evolution of pore-forming domains}

The structure relatedness between $\beta$-PFTs and BCs strongly suggests that all $\beta$-PFTs and BCs have evolved from a common ancestor, possibly a transmembrane protein. BCs have retained a core structure of $\beta$-PFTs, and they have acquired the ability to recognize and translocate specific enzymatic components, whereas $\beta$-PFTs form pores in plasma membrane of eukaryotic cells leading to drastic cellular effects (Fig. 8). It is intriguing that homologues of aerolysin and CDC families are wide spread in all the kingdoms of life. As mentioned 
above, structural homologous proteins of aerolysin (hydralysins, enterolobin, LSL, ...) are produced by plants, fungi and animals [80]. In addition, more than 300 proteins from diverse groups of organisms share aerolysin domain similarity based on local sequence alignment and phylogenetic analysis. It is hypothesized that these proteins derive from a common ancestor probably in early bacterial lineages, which has been transmitted between organisms of different phylum by horizontal gene transfer. This analysis suggests that at least six independent transfer events have occurred between distantly related organisms including between bacteria and eukaryotic cells [196]. The structural homology between MACPF and $\mathrm{CDC}$ proteins restricted to the pore-forming domain, whereas the other domains are distantly related [31], rather suggests a convergent evolution of eukaryote and prokaryote proteins of these families to interact with the lipid bilayer.

\section{7 - Concluding remarks}

Pore formation is a common mechanism of action for many bacterial toxins including clostridial toxins. Disruption of the membrane integrity of cell host is a direct and an efficient way for a pathogen to have access to indispensable nutrients and seems to be the ancestor mode of action of most of bacterial toxins. Structural analysis put in light that all clostridial PFTs derive probably from a common ancestor and retain a similar global mode of insertion into lipid membrane including the formation of an amphipatic $\beta$-barrel, which inserts into the lipid bilayer leading to a functional pore. During the evolution, certain PFTs have acquired additional or more specialized function possibly in order to address specific requirements of pathogens. Thereby, instead to interact with an ubiquitous receptor on cell surface and to form large pores which abruptly impair the membrane integrity, heptameric PFTs target receptors specific of some cell types and induce small pores with subsequent intracellular signaling leading to specific response like attack of the nervous system, the vascular endothelial barrier, or the intestinal epithelial barrier. A more specialized pore forming activity concerns the intracellular active toxins. Binding components of binary toxins have evolved from $\beta$-PFTs to selectively mediate the translocation of the enzymatic components through the endosomal membrane at the acidic $\mathrm{pH}$ of endosome. In contrast, intracellularly active single chain protein toxins retain a different mode of insertion into the lipid bilayer based on $\alpha$-helices. The selective pressure, which has controlled the evolution of $\beta$ - and $\alpha$-pore forming structures, remains mysterious. We can hypothesize that $\beta$-pore formation, which results from a more complex structure and mechanism than those of $\alpha$-pore forming proteins, confer 
selective advantages in stability, efficiency in pore forming activity and beneficial cellular effects for the bacterial pathogens, notably in terms of bacterial growth and dissemination in the host. 


\section{References}

[1] Alouf JE. Molecular features of the cytolytic pore forming bacterial protein toxins. Fol Microbiol 2003;48:5-16.

[2] Gonzalez MR, Bischofberger M, Pernot L, van der Goot FG, Freche B. Bacterial poreforming toxins: the (w)hole story? Cell Mol Life Sci 2008;65:493-507.

[3] Parker MW, Feil SC. Pore-forming protein toxins: from structure to function. Prog Biophys Mol Biol 2005;88:91-142.

[4] Popoff MR, Bouvet P. Clostridial toxins. Future Microbiol 2009;4:1021-64.

[5] Gilbert RJ, Mikelj M, Dalla Serra M, Froelich CJ, Anderluh G. Effects of MACPF/CDC proteins on lipid membranes. Cell Mol Life Sci 2013;70:2083-98. doi: 10.1007/s00018-012-1153-8. Epub 2012 Sep 15.

[6] Kondos SC, Hatfaludi T, Voskoboinik I, Trapani JA, Law RH, Whisstock JC, et al. The structure and function of mammalian membrane-attack complex/perforin-like proteins. Tissue Antigens 2010;76:341-51. doi: 10.1111/j.399-0039.2010.01566.x. Epub 2010 Sep 22.

[7] Jakes KS, Cramer WA. Border crossings: colicins and transporters. Annu Rev Genet 2012;46:209-31.:10.1146/annurev-genet-110711-55427. Epub 2012 Aug 28.

[8] Cascales E, Buchanan SK, Duche D, Kleanthous C, Lloubes R, Postle K, et al. Colicin biology. Microbiol Mol Biol Rev 2007;71:158-229.

[9] Bermejo IL, Arnulphi C, Ibanez de Opakua A, Alonso-Marino M, Goni FM, Viguera AR. Membrane partitioning of the pore-forming domain of colicin A. Role of the hydrophobic helical hairpin. Biophys J 2013;105:1432-43. doi: 10.016/j.bpj.2013.08.012.

[10] Ladokhin AS. pH-triggered conformational switching along the membrane insertion pathway of the diphtheria toxin T-domain. Toxins (Basel) 2013;5:136280. doi: $10.3390 /$ toxins5081362.

[11] Murphy JR. Mechanism of diphtheria toxin catalytic domain delivery to the eukaryotic cell cytosol and the cellular factors that directly participate in the process. Toxins (Basel) 2011;3:294-308. doi: 10.3390/toxins3030294. Epub 2011 Mar 21.

[12] Senzel L, Gordon M, Blaustein RO, Oh KJ, Collier RJ, Finkelstein A. Topography of diphtheria Toxin's $\mathrm{T}$ domain in the open channel state. J Gen Physiol 2000;115:421-34.

[13] Wallace AJ, Stillman TJ, Atkins A, Jamieson SJ, Bullough PA, Green J, et al. E. coli hemolysin E (hlyE, ClyA, SheA): X-ray crystal structure of the toxin and observation of membrane pores by electron microscopy. Cell 2000;100:265-76.

[14] Fahie M, Romano FB, Chisholm C, Heuck AP, Zbinden M, Chen M. A non-classical assembly pathway of Escherichia coli pore-forming toxin cytolysin A. J Biol Chem 2013;288:31042-51. doi: 10.1074/jbc.M113.475350. Epub 2013 Sep 9.

[15] Hunt S, Green J, Artymiuk PJ. Hemolysin E (HlyE, ClyA, SheA) and related toxins. Adv Exp Med Biol 2010;677:116-26. 
[16] Geny B, Popoff MR. Bacterial protein toxins and lipids: pore formation or toxin entry into cells. Biol Cell 2006;98:667-78.

[17] Alouf J. Cholesterol binding toxins (Streptococcus, Bacillus, Clostridium, Listeria). In: Rappuoli R, Montecucco C, editors. Guidebook to Protein Toxins and their Use in Cell Biology. Oxford: Sambrook \& Tooze Publications; 1997, p. 7-10.

[18] Tweten RK. Cholesterol-dependent cytolysins, a family of versatile pore-forming toxins. Infect Immun 2005;73:6199-209.

[19] Deguchi A, Miyamoto K, Kuwahara T, Miki Y, Kaneko I, Li J, et al. Genetic characterization of type A enterotoxigenic Clostridium perfringens strains. PLoS One 2009;4:e5598.

[20] Katayama S, Dupuy B, Cole ST. Rapid expansion of the physical and genetic map of the chromosome of Clostridium perfringens CPN50. J Bacteriol 1995;177:5680-5.

[21] Shimizu T, Ohtani K, Hirakawa H, Ohshima K, Yamashita A, Shiba T, et al. Complete genome sequence of Clostridium perfringens, an anaerobic flesh-eater. Proc Natl Acad Sci (USA) 2002;99:996-1001.

[22] Tweten RK. Nucleotide sequence of the gene for perfringolysin 0 (theta toxin) from Clostridium perfringens: significant homology with the genes for streptolysin and pneumolysin. Infect Immun 1988;56:3235-40.

[23] Rossjohn J, Feil SC, McKinstry WJ, Tweten RK, Parker MW. Structure of a cholesterol-binding thiol-activated cytolysin and a model of its membrane form. Cell 1997;89:685-92.

[24] Soltani CE, Hotze EM, Johnson AE, Tweten RK. Structural elements of the cholesterol-dependent cytolysins that are responsible for their cholesterolsensitive membrane interactions. Proc Natl Acad Sci U S A 2007;104:20226-31.

[25] Waheed AA, Shimada Y, Heijnen HFG, Nakamura M, Inomata M, Hayashi M, et al. Selective binding of perfringolysin $O$ derivative to cholesterol-rich membrane microdomùains (rafts). Proc Ntl Acad Sci (USA) 2001;98:4926-31.

[26] Farrand AJ, LaChapelle S, Hotze EM, Johnson AE, Tweten RK. Only two amino acids are essential for cytolytic toxin recognition of cholesterol at the membrane surface. Proc Natl Acad Sci U S A 2010;107:4341-6. doi: 10.1073/pnas.0911581107. Epub 2010 Feb 9.

[27] Rossjohn J, Polekhina G, Feil SC, Morton CJ, Tweten RK, Parker MW. Structures of perfringolysin 0 suggest a pathway for activation of cholesterol-dependent cytolysins. J Mol Biol 2007;367:1227-36.

[28] Heuck AP, Savva CG, Holzenburg A, Johnson AE. Conformational changes that effect oligomerization and initiate pore formation are triggered throughout perfringolysin 0 upon binding to cholesterol. J Biol Chem 2007;282:22629-37.

[29] Dowd KJ, Tweten RK. The cholesterol-dependent cytolysin signature motif: a critical element in the allosteric pathway that couples membrane binding to pore assembly. PLoS Pathog 2012;8:e1002787.

[30] Shepard L, Shatursky O, Johnson A, Tweten R. The mechanism of pore assembly for a cholesterol-dependent cytolysin: formation of a large prepore complex precedes the insertion of hte transmembrane $\beta$-hairpins. Biochemistry 2000;39:10284-93. 
[31] Dunstone MA, Tweten RK. Packing a punch: the mechanism of pore formation by cholesterol dependent cytolysins and membrane attack complex/perforin-like proteins. Curr Opin Struct Biol 2012;22:342-9.

[32] Heuck AP, Moe PC, Johnson BB. The cholesterol-dependent cytolysin family of gram-positive bacterial toxins. Subcell Biochem 2010;51:551-77.

[33] Hotze EM, Tweten RK. Membrane assembly of the cholesterol-dependent cytolysin pore complex. Biochim Biophys Acta 2012;1818:1028-38.

[34] Ramachandran R, Tweten RK, Johnson AE. Membrane-dependent conformational changes initiate cholesterol-dependent cytolysin oligomerization and intersubunit $\beta$-strand alignment. Nat Struct Mol Biol 2004;11:697-705.

[35] Ramachandran R, Heuck AP, Tweten RK, Johnson AE. Structural insights into the membrane-anchoring mechanism of a cholesterol-dependent cytolysin. Nat Struct Biol 2002;9:823-7.

[36] Heuck AP, Hotze EM, Tweten RK, Johnson AE. Mechanism of membrane insertion of a multimeric beta-barrel protein: perfringolysin 0 creates a pore using ordered and coupled conformational changes. Mol Cell 2000;6:1233-42.

[37] Heuck AP, Tweten RK, Johnson AE. $\beta$-barrel pore-forming toxins: intriguing dimorphic proteins. Biochemistry 2001;40:9065-73.

[38] Shatursky O, Heuck A, Shepard L, Rossjhon J, Parker M, Johnson A, et al. The mechanism of membrane insertion of a cholesterol-dependent cytolysin: a novel paradigm for pore-forming toxins. Cell 1999;99:293-9.

[39] Hotze EM, Heuck AP, Czajkowsky DM, Shao Z, Johnson AE, Tweten RK. Monomermonomer interactions drive the prepore to pore conversion of a $\beta$-barrel-forming cholesterol-dependent cytolysin. J Biol Chem 2002;277:11597-605.

[40] Czajkowsky DM, Hotze EM, Shao Z, Tweten RK. Vertical collapse of a cytolysin prepore moves its transmembrane beta-hairpins to the membrane. Embo J 2004;23:3206-15.

[41] Dang TX, Hotze EM, Rouiller I, Tweten RK, Wilson-Kubalek EM. Prepore to pore transition of a cholesterol-dependent cytolysin visualized by electron microscopy. J Struct Biol 2005;150:100-8.

[42] Sato TK, Tweten RK, Johnson AE. Disulfide-bond scanning reveals assembly state and beta-strand tilt angle of the PFO beta-barrel. Nat Chem Biol 2013;9:383-9. doi: 10.1038/nchembio.228. Epub 2013 Apr 7.

[43] Nelson LD, Johnson AE, London E. How interaction of perfringolysin 0 with membranes is controlled by sterol structure, lipid structure, and physiological low $\mathrm{pH}$ : insights into the origin of perfringolysin O-lipid raft interaction. J Biol Chem 2008;283:4632-42.

[44] Madden JC, Ruiz H, Caparon M. Cytolysin-mediated translocation (CMT): a functional equivalent of type III secretion in Gram-positive bacteria. Cell 2001;104:143-52.

[45] Meehl MA, Caparon MG. Specificity of streptolysin 0 in cytolysin-mediated translocation. Mol Microbiol 2004;52:1665-76. 
[46] Hamon MA, Ribet D, Stavru F, Cossart P. Listeriolysin O: the Swiss army knife of Listeria. Trends Microbiol 2012;20:360-8. doi: 10.1016/j.tim.2012.04.006. Epub May 30.

[47] Schnupf P, Portnoy DA. Listeriolysin 0: a phagosome-specific lysin. Microbes Infect 2007;9:1176-87. Epub 2007 May 7.

[48] Awad MM, Bryant AE, Stevens DL, Rood JI. Virulence studies on chromosomal alpha-toxin and theta-toxin mutants constructed by allelic exchange provide genetic evidence for the essential role of alpha-toxin in Clostridium perfringensmediated gas gangrene. Mol Microbiol 1995;15:191-202.

[49] Awad MM, Ellemor DM, Boyd RL, Emmins JJ, Rood JI. Synergistic effects of alphatoxin and perfringolysin 0 in Clostridium perfringens-mediated gas gangrene. Infect Immun 2001;69:7904-10.

[50] Stevens DL, Tweten RK, Awad MM, Rood JI, Bryant AE. Clostridial gas gangrene: evidence that alpha and theta toxins differentially modulate the immune response and induce acute tissue necrosis. J Infect Dis 1997;176:189-95.

[51] Harris RW, Sims PJ, Tweten RK. Evidence that Clostridium perfringens theta-toxin induces colloid-osmotic lysis of erythrocytes. Infect Immun 1991;59:2499-501.

[52] Ribet D, Hamon M, Gouin E, Nahori MA, Impens F, Neyret-Kahn H, et al. Listeria monocytogenes impairs SUMOylation for efficient infection. Nature 2010;464:1192-5. doi: 10.038/nature08963.

[53] Bryant AE, Bergstrom R, Zimmerman GA, Salyer JL, Hill HR, Tweten RK, et al. Clostridium perfringens invasiveness is enhanced by effects of theta toxin upon PMNL structure and function: The roles of leukocytotoxicity and expression of CD11/CD18 adherence glycoprotein. FEMS Immunol Med Microbiol 1993;7:321-6.

[54] Stevens DL, Mitten J, Henry C. Effects of alpha and theta toxins from Clostridium perfringens on human polymorphonuclear leukocytes. J Infect Dis 1987;156:32433.

[55] O'Brien DK, Melville SB. The anaerobic pathogen Clostridium perfringens can escape the phagosome of macrophages under aerobic conditions. Cell Microbiol 2000;2:505-19.

[56] O'Brien DK, Melville SB. Effects of Clostridium perfringens alpha-toxin (PLC) and perfringolysin $\mathrm{O}$ (PFO) on cytotoxicity to macrophages, on escape from the phagosomes of macrophages, and on persistence of C. perfringens in host tissues. Infect Immun 2004;72:5204-15.

[57] Bryant AE, Stevens DL. Phospholipase C and perfringolysin O from Clostridium perfringens upregulate endothelial cell-leukocyte adherence molecule 1 and intercellular leukocyte adherence molecule 1 expression and induce interleukin-8 synthesis on cultured human umbilical vein endothelial cells. Infect Immun 1996;64:358-62.

[58] Bunting M, Lorant DE, Bryant AE, Zimmerman GA, Mcintyre TM, Stevens DL, et al. Alpha toxin from Clostridium perfringens induces proinflammatory changes in endothelial cells. J Clin Invest 1997;100:565-74. 
[59] Bryant AE, Bayer CR, Hayes-Schroer SM, Stevens D. Activation of platelet gpIIIa by phospholipase C from Clostridium perfringens involves store-operated calcium entry. J Infect Dis 2003;187:408-17.

[60] Bryant AE, Chen RY, Nagata Y, Wang Y, Lee CH, Finegold S, et al. Clostridial gas gangrene. II. Phospholipase $\mathrm{C}$-induced activation of platelet gpIIbIIIa mediates vascular occlusion and myonecrosis in Clostridium perfringens gas gangrene. J Infect Dis 2000;182:808-15. Epub 2000 Aug 17.

[61] Bryant AE, Chen RY, Nagata Y, Wang Y, Lee CH, Finegold S, et al. Clostridial gas gangrene. I. Cellular and molecular mechanisms of microvascular dysfunction induced by exotoxins of Clostridium perfringens. J Infect Dis 2000;182:799-807. Epub 2000 Aug 17.

[62] Hickey MJ, Kwan RY, Awad MM, Kennedy CL, Young LF, Hall P, et al. Molecular and cellular basis of microvascular perfusion deficits induced by Clostridium perfringens and Clostridium septicum. PLoS Pathog 2008;4:e1000045.

[63] Stevens DL. The pathogenesis of clostridial myonecrosis. Int J Med Microbiol 2000;290:497-502.

[64] Stevens DL, Aldape MJ, Bryant AE. Life-threatening clostridial infections. Anaerobe 2012;18:254-9. doi: 10.1016/j.anaerobe.2011.11.001. Epub Nov 20.

[65] Stevens DL, Bryant AE. The role of Clostridial toxins in the pathogenesis of gas gangrene. Clin Infect Dis 2002;35:S93-S100.

[66] Stevens DL, Troyer BE, Merrick DT, Mitten JE, Olson RD. Lethal effects and cardiovascular effects of purified $\alpha$ - and $\Theta$-toxins from Clostridium perfringens. J Infect Dis 1988;157:272-9.

[67] Asmuth DM, Olson RD, Hackett SP, Bryant AE, Tweten RK, Tso JY, et al. Effects of Clostridium perfringens recombinant and crude phospholipase $\mathrm{C}$ and theta-toxin on rabbit hemodynamic parameters. J Infect Dis 1995;172:1317-23.

[68] Stevens DL, Bryant AE. Pathogenesis of Clostridium perfringens infection: mechanisms and mediators of shock. Clin Infect Dis 1997;25:S160-4.

[69] Keyel PA, Heid ME, Salter RD. Macrophage responses to bacterial toxins: a balance between activation and suppression. Immunol Res 2011;50:118-23. doi: 10.1007/s12026-011-8212-3.

[70] Sugimoto N, Haque A, Horiguchi Y, Matsuda M. Coronary vasoconstriction is the most probable cause of death of rats intoxicated with botulinolysin, a hemolysin produced by Clostridium botulinum. Toxicon 1995;33:1215-30.

[71] Sugimoto N, Haque A, Horiguchi Y, Matsuda M. Botulinolysin, a thiol-activated hemolysin produced by Clostridium botulinum, inhibits endothelium-dependent relaxation of rat aortic ring. Toxicon 1997;35:1011-23.

[72] Iacovache I, Bischofberger M, van der Goot FG. Structure and assembly of poreforming proteins. Curr Opin Struct Biol 2010;20:241-6. doi: 10.1016/j.sbi.2010.01.013. Epub Feb 19.

[73] Briggs DC, Naylor CE, Smedley JG, 3rd, Lukoyanova N, Robertson S, Moss DS, et al. Structure of the food-poisoning Clostridium perfringens enterotoxin reveals similarity to the aerolysin-like pore-forming toxins. J Mol Biol 2011;413:138-49. 
[74] Cole AR, Gibert M, Popoff MR, Moss DS, Titball RW, Basak A. Clostridium perfringens $\varepsilon$-toxin shows structural similarity to the pore-forming toxin aerolysin. Nat Struct Mol Biol 2004;11:797-8.

[75] Kitadokoro K, Nishimura K, Kamitani S, Fukui-Miyazaki A, Toshima H, Abe H, et al. Crystal structure of Clostridium perfringens enterotoxin displays features of betapore-forming toxins. J Biol Chem 2011;286:19549-55.

[76] Melton JA, Tweten RK. Clostridium septicum pore-forming $\alpha$-toxin. In: Alouf JE, Popoff MR, editors. The Comprehensive Sourcebook of Bacterial Protein Toxins. Amsterdam: Elsevier, Academic Press; 2006, p. 623-30.

[77] Melton-Witt JA, Bentsen LM, Tweten RK. Identification of functional domains of Clostridium septicum alpha toxin. Biochemistry 2006;45:14347-54.

[78] Ballard J, Crabtree J, Roe BA, Tweten RK. The primary structure of Clostridium septicum alpha-toxin exhibits similarity with that of Aeromonas hydrophila aerolysin. Infect Immun 1995;63:340-4.

[79] De Colibus L, Sonnen AF, Morris KJ, Siebert CA, Abrusci P, Plitzko J, et al. Structures of lysenin reveal a shared evolutionary origin for pore-forming proteins and its mode of sphingomyelin recognition. Structure 2012;20:1498-507.

[80] Knapp 0, Stiles BG, Popoff MR. The aerolysin-like toxin family of cytolytic, poreforming toxins. Open Toxinol J 2010;3:53-68.

[81] Szczesny P, Iacovache I, Muszewska A, Ginalski K, van der Goot FG, Grynberg M. Extending the aerolysin family: from bacteria to vertebrates. PLoS One 2011;6:e20349. doi: 10.1371/journal.pone.0020349. Epub 2011 Jun 8.

[82] Gurcel L, Iacovache I, van der Goot FG. Aerolysin and related Aeromonas toxins. In: Alouf JE, Popoff MR, editors. The Source Book of Bacterial Protein Toxins. $3^{\circ}$ ed. Amsterdam Elsevier, Academic Press; 2006, p. 606-20.

[83] McClane BA. Clostridium perfringens enterotoxin. In: Alouf JE, Popoff MR, editors. The Comprehensive Sourcebook of Bacterial Protein Toxins. $3^{\circ}$ ed. Amsterdam: Elsevier, Academic Press; 2006, p. 763-78.

[84] Minami J, Katayama S, Matsushita O, Matsushita C, Okabe A. Lambda-toxin of Clostridium perfringens activates the precursor of epsilon-toxin by releasing its $\mathrm{N}$ and C-terminal peptides. Microbiol Immunol 1997;41:527-35.

[85] Ballard J, Sokolov Y, Yuan WL, Kagan BL, Tweten RK. Activation and mechanism of Clostridium septicum alpha toxin. Mol Microbiol 1993;10:627-34.

[86] Sellman BR, Tweten RK. The propeptide of Clostridium septicum alpha toxin functions as an intramolecular chaperone and is a potent inhibitor of alpha toxindependent cytolysis. Mol Microbiol 1997;25:429-40.

[87] Iacovache I, van der Goot FG, Pernot L. Pore formation: an ancient yet complex form of attack. Biochim Biophys Acta 2008;1778:1611-23. doi: 10.016/j.bbamem.2008.01.026. Epub Feb 12.

[88] Cole A. Structural studies on epsilon toxin from Clostridium perfringens. In: Duchesnes C, Mainil J, Popoff MR, Titball R, editors. Protein toxins of the genus Clostridium and vaccination. Liège: Presses de la Faculté de Médecine Vétérinaire; 2003, p. 95. 
[89] Ivie SE, McClain MS. Identification of Amino Acids Important for Binding of Clostridium perfringens Epsilon Toxin to Host Cells and to HAVCR1. Biochemistry 2012;51:7588-95.

[90] Gordon VM, Nelson KL, Buckley JT, Stevens VL, Tweten RK, Elwood PC, et al. Clostridium septicum alpha-toxin uses glycosylphosphatidylinositol-anchored protein receptors. J Biol Chem 1999;274:27274-80.

[91] Fujita K, Katahira J, Horiguchi Y, Sonoda N, Furuse M, Tsukita S. Clostridium perfringens enterotoxin binds to the second extracellualr loop of claudin-3, a tight junction integral membrane protein. FEBS Lett 2000;476:258-61.

[92] Veshnyakova A, Piontek J, Protze J, Waziri N, Heise I, Krause G. Mechanism of Clostridium perfringens enterotoxin interaction with claudin-3/-4 protein suggests structural modifications of the toxin to target specific claudins. J Biol Chem 2012;287:1698-708.

[93] Ivie SE, Fennessey CM, Sheng J, Rubin DH, McClain MS. Gene-Trap Mutagenesis Identifies Mammalian Genes Contributing to Intoxication by Clostridium perfringens epsilon-Toxin. PLoS One 2011;6:e17787.

[94] Iacovache I, Paumard P, Scheib H, Lesieur C, Sakai N, Matile S, et al. A rivet model for channel formation by aerolysin-like pore-forming toxins. Embo J 2006;25:45766.

[95] Masson JB, Casanova D, Turkcan S, Voisinne G, Popoff MR, Vergassola M, et al. Inferring maps of forces inside cell membrane microdomains. Phys Rev Lett 2009;102:048103.

[96] Miyata S, Minami J, Tamai E, Matsushita O, Shimamoto S, Okabe A. Clostridium perfringens $\varepsilon$-toxin forms a heptameric pore within the detergent-insoluble microdomains of Madin-Darby Canine Kidney Cells and rat synaptosomes. J Biol Chem 2002;277:39463-8.

[97] Chassin C, Bens M, de Barry J, Courjaret R, Bossu JL, Cluzeaud F, et al. Pore-forming epsilon toxin causes membrane permeabilization and rapid ATP depletionmediated cell death in renal collecting duct cells. Am J Physiol Renal Physiol 2007;293:F927-37.

[98] Turkcan S, Masson JB, Casanova D, Mialon G, Gacoin T, Boilot JP, et al. Observing the confinement potential of bacterial pore-forming toxin receptors inside rafts with nonblinking eu(3+)-doped oxide nanoparticles. Biophys J 2012;102:2299308.

[99] Turkcan S, Richly MU, Alexandrou A, Masson JB. Probing membrane protein interactions with their lipid raft environment using single-molecule tracking and Bayesian inference analysis. PLoS One 2013;8:e53073. doi: 10.1371/journal.pone.0053073. Epub 2013 Jan 3.

[100]Turkcan S, Richly MU, Bouzigues CI, Allain JM, Alexandrou A. Receptor displacement in the cell membrane by hydrodynamic force amplification through nanoparticles. Biophys J 2013;105:116-26. doi: 10.1016/j.bpj.2013.05.045.

[101]Degiacomi MT, Iacovache I, Pernot L, Chami M, Kudryashev M, Stahlberg H, et al. Molecular assembly of the aerolysin pore reveals a swirling membrane-insertion 
mechanism. Nat Chem Biol 2013;9:623-9. doi: 10.1038/nchembio.312. Epub 2013

[102] Kennedy CL, Smith DJ, Lyras D, Chakravorty A, Rood JI. Programmed cellular necrosis mediated by the pore-forming alpha-toxin from Clostridium septicum. PLoS Pathog 2009;5:e1000516.

[103]Knapp 0, Maier E, Mkaddem SB, Benz R, Bens M, Chenal A, et al. Clostridium septicum alpha-toxin forms pores and induces rapid cell necrosis. Toxiconj 2010;55:61-72.

[104]Petit L, Gibert M, Gourch A, Bens M, Vandewalle A, Popoff MR. Clostridium perfringens Epsilon Toxin rapidly decreases membrane barrier permeability of polarized MDCK Cells. Cell Microbiol 2003;5:155-64.

[105]Knapp 0, Maier E, Mkaddem SB, Benz R, Bens M, Chenal A, et al. Clostridium septicum alpha-toxin forms pores and induces rapid cell necrosis. Toxicon 2010;55:61-72.

[106]Popoff MR. Epsilon toxin: a fascinating pore-forming toxin. Febs J 2011;278:460215.

[107]Bokori-Brown M, Savva CG, Fernandes da Costa SP, Naylor CE, Basak AK, Titball RW. Molecular basis of toxicity of Clostridium perfringens epsilon toxin. Febs J 2011;278:4589-601.

[108]Wioland L, Dupont JL, Bossu JL, Popoff MR, Poulain B. Attack of the nervous system by Clostridium perfringens Epsilon toxin: from disease to mode of action on neural cells. Toxicon 2013;75:122-35.:10.1016/j.toxicon.2013.04.003. Epub Apr 27.

[109]Bischofberger M, Iacovache I, van der Goot FG. Pathogenic pore-forming proteins: function and host response. Cell Host Microbe 2012;12:266-75. doi: 10.1016/j.chom.2012.08.005.

[110]Lonchamp E, Dupont JL, Wioland L, Courjaret R, Mbebi-Liegeois C, Jover E, et al. Clostridium perfringens epsilon toxin targets granule cells in the mouse cerebellum and stimulates glutamate release. PLoS One 2010;5:e13046.

[111]Chakrabarti G, McClane BA. The importance of calcium influx, calpain and calmodulin for the activation of CaCo-2 cell death pathways by Clostridium perfringens enterotoxin. Cell Microbiol 2005;7:129-46.

[112]Rumah KR, Linden J, Fischetti VA, Vartanian T. Isolation of Clostridium perfringens type B in an individual at first clinical presentation of multiple sclerosis provides clues for environmental triggers of the disease. PLoS One 2013;8:e76359. doi: 10.1371/journal.pone.0076359. eCollection 2013.

[113]Tweten RK. Clostridium perfringens beta toxin and Clostridium septicum alpha toxin: their mechanisms and possible role in pathogenesis. Vet Microbiol 2001;82:1-9.

[114]Uzal FA, Songer JG. Diagnosis of Clostridium perfringens intestinal infections in sheep and goats. J Vet Diagn Invest 2008;20:253-65.

[115]Lindsay JA. Clostridium perfringens type A enterotoxin (CPE): more than just explosive diarrhea. Crit Rev Microbiol 1996;22:257-77. 
[116]Sparks SG, Carman RJ, Sarker MR, McClane BA. Genotyping of enterotoxigenic Clostridium perfringens fecal isolates associated with antibiotic-associated diarrhea and food poisoning in North America. J Clin Microbiol 2001;39:883-8.

[117]Lindstrom M, Heikinheimo A, Lahti P, Korkeala H. Novel insights into the epidemiology of Clostridium perfringens type A food poisoning. Food Microbiol 2011;28:192-8.

[118]Modi N, Wilcox MH. Evidence for antibiotic induced Clostridium perfringens diarrhoea. J Clin Pathol 2001;54:748-51.

[119]Collie RE, Kokai-Kun JF, McClane BA. Phenotypic characterization of enterotoxigenic Clostridium perfringens isolates from non-foodborne human gastrointestinal diseases. Anaerobe 1998;4:69-79.

[120]Kobayashi S, Wada A, Shibasaki S, Annaka M, Higuchi H, Adachi K, et al. Spread of a large plasmid carrying the cpe gene and the tcp locus amongst Clostridium perfringens isolates from nosocomial outbreaks and sporadic cases of gastroenteritis in a geriatric hospital. Epidemiol Infect 2009;137:108-13.

[121]Banaszkiewicz A, Kadzielska J, Gawronska A, Pituch H, Obuch-Woszczatynski P, Albrecht P, et al. Enterotoxigenic Clostridium perfringens infection and pediatric patients with inflammatory bowel disease. J Crohns Colitis 2013;21:00311-5.

[122]Petit L, Gibert M, Popoff MR. Clostridium perfringens enterotoxin and C. perfringens food poisoning. In: Robinson R, Batt C, Patel P, editors. Encyclopedia of Food microbiology. London: Academic Press; 1999, p. 438-44.

[123]Savva CG, Fernandes da Costa SP, Bokori-Brown M, Naylor CE, Cole AR, Moss DS, et al. Molecular architecture and functional analysis of NetB, a pore-forming toxin from Clostridium perfringens. J Biol Chem 2013;288:3512-22.

[124]Yan XX, Porter CJ, Hardy SP, Steer D, Smith AI, Quinsey NS, et al. Structural and functional analysis of the pore-forming toxin NetB from Clostridium perfringens. MBio 2013;4:e00019-13. doi: 10.1128/mBio.-13.

[125]Huyet J, Naylor CE, Savva CG, Gibert M, Popoff MR, Basak AK. Structural Insights into Delta Toxin Pore Formation. PLoS One 2013;8:e66673. Print 2013.

[126]Manich M, Knapp O, Gibert M, Maier E, Jolivet-Reynaud C, Geny B, et al. Clostridium perfringens delta toxin is sequence related to beta toxin, NetB, and Staphylococcus pore-forming toxins, but shows functional differences. PLoS ONE 2008;3:e3764.

[127]Prevost G, Mourey L, Colin DA, Menestrina G. Staphylococcal pore-forming toxins. Curr Top Microbiol Immunol 2001;257:53-83.

[128]Menestrina G, Dalla Serra M, Comai M, Coraiola M, Viero G, Werner S, et al. Ion channels and bacterial infection: the case of beta-barrel pore-forming protein toxins of Staphylococcus aureus. FEBS Lett 2003;552:54-60.

[129]Berube BJ, Bubeck Wardenburg J. Staphylococcus aureus alpha-toxin: nearly a century of intrigue. Toxins (Basel) 2013;5:1140-66.

[130]Song L, Hobaugh MR, Shustak C, Cheley S, Bayley H, Gouaux JE. Structure of staphylococcal alpha-hemolysin, a heptameric transmembrane pore. Science 1996;274:1859-66. 
[131]Jolivet-Reynaud C, Estrada J, West LA, Alouf JE, Chedid L. Targeting of GM2-bearing tumor cells with the cytolytic Clostridium perfringens delta toxin. Anti Cancer Drugs 1993;4:65-75.

[132]Hunter SE, Brown E, Oyston PCF, Sakurai J, Titball RW. Molecular genetic analysis of beta-toxin of Clostridium perfringens reveals sequence homology with alphatoxin, gamma-toxin, and leukocidin of Staphylococcus aureus. Infect Immun 1993;61:3958-65.

[133]Gibert M, Perelle S, Daube G, Popoff MR. Clostridium spiroforme toxin genes are related to $C$. perfringens iota toxin genes but have a different genomic localization. Syst Appl Microbiol 1997;20:337-47.

[134]Popoff MR, Bouvet P. Genetic characteristics of toxigenic Clostridia and toxin gene evolution. Toxicon 2013;23:00184-0.

[135]Inoshima I, Inoshima N, Wilke GA, Powers ME, Frank KM, Wang Y, et al. A Staphylococcus aureus pore-forming toxin subverts the activity of ADAM10 to cause lethal infection in mice. Nat Med 2011;17:1310-4. doi: 10.038/nm.2451.

[136]Wilke GA, Bubeck Wardenburg J. Role of a disintegrin and metalloprotease 10 in Staphylococcus aureus alpha-hemolysin-mediated cellular injury. Proc Natl Acad Sci U S A 2010;107:13473-8.

[137]Prévost G, Mourey L, Colin DA, Monteil H, Dalla sera M, Menestrina G. Alpha-helix and beta-barrel pore-forming toxins (leucocidins, alpha-, gamma-, and deltacytolysins) of Staphylococcus aureus. In: Alouf JE, Popoff MR, editors. The Comprehensive Sourcebook of Bacterial Protein Toxins. $3^{\circ}$ ed. Amsterdam: Elsevier Academic Press; 2006, p. 590-607.

[138]Bischofberger M, Gonzalez MR, van der Goot FG. Membrane injury by pore-forming proteins. Curr Opin Cell Biol 2009;21:589-95. doi: 10.1016/j.ceb.2009.04.003. Epub May 11.

[139]Powers ME, Kim HK, Wang Y, Bubeck Wardenburg J. ADAM10 mediates vascular injury induced by Staphylococcus aureus alpha-hemolysin. J Infect Dis 2012;206:352-6. doi: 10.1093/infdis/jis192. Epub 2012 Apr 2.

[140]Steinthorsdottir V, Halldorson H, Andresson O. Clostridium perfringens beta-toxin forms multimeric transmembrane pores in human endothelial cells. Microb Pathog 2000;28:45-50.

[141]Shatursky O, Bayles R, Rogers M, Jost BH, Songer JG, Tweten RK. Clostridium perfringens beta-toxin forms potential-dependent, cation-selective channels in lipid bilayers. Infect Immun 2000;68:5546-51.

[142]Nagahama M, Hayashi H, Morimitsu S, Sakurai J. Biological activities and pore formation of Clostridiium perfringens Beta toxin in HL60 cells. J Biol Chem 2003;278:36934-41.

[143]Nagahama M, Morimitsu S, Kihara A, Akita M, Setsu K, Sakurai J. Involvement of tachykinin receptors in Clostridium perfringens beta-toxin-induced plasma extravasation. Br J Pharmacol 2003;138:23-30. 
[144]Nagahama M, Kihara A, Kintoh H, Oda M, Sakurai J. Involvement of tumour necrosis factor-alpha in Clostridium perfringens beta-toxin-induced plasma extravasation in mice. Br J Pharmacol 2008;153:1296-302.

[145]Nagahama M, Shibutani M, Seike S, Yonezaki M, Takagishi T, Oda M, et al. The p38 MAPK and JNK pathways protect host cells against Clostridium perfringens betatoxin. Infect Immun 2013;81:3703-8. doi: 10.1128/IAI.00579-13. Epub 2013 Jul 22.

[146]Vidal JE, McClane BA, Saputo J, Parker J, Uzal FA. Effects of Clostridium perfringens beta-toxin on the rabbit small intestine and colon. Infect Immun 2008;76:4396404.

[147]Miclard J, Jaggi M, Sutter E, Wyder M, Grabscheid B, Posthaus H. Clostridium perfringens beta-toxin targets endothelial cells in necrotizing enteritis in piglets. Vet Microbiol 2009;137:320-5. doi: 10.1016/j.vetmic.2009.01.025. Epub Jan 22.

[148]Miclard J, van Baarlen J, Wyder M, Grabscheid B, Posthaus H. Clostridium perfringens beta-toxin binding to vascular endothelial cells in a human case of enteritis necroticans. J Med Microbiol 2009;58:826-8. doi: 10.1099/jmm.0.0080600 .

[149]Schumacher VL, Martel A, Pasmans F, Van Immerseel F, Posthaus H. Endothelial binding of beta toxin to small intestinal mucosal endothelial cells in early stages of experimentally induced Clostridium perfringens type C enteritis in pigs. Vet Pathol 2013;50:626-9. doi: 10.1177/0300985812461362. Epub 2012 Sep 24.

[150]Gurtner C, Popescu F, Wyder M, Sutter E, Zeeh F, Frey J, et al. Rapid cytopathic effects of Clostridium perfringens beta-toxin on porcine endothelial cells. Infect Immun 2010;78:2966-73. doi: 10.1128/IAI.01284-09. Epub 2010 Apr 19.

[151]Popescu F, Wyder M, Gurtner C, Frey J, Cooke RA, Greenhill AR, et al. Susceptibility of primary human endothelial cells to $C$. perfringens beta-toxin suggesting similar pathogenesis in human and porcine necrotizing enteritis. Vet Microbiol 2011;153:173-7. doi: 10.1016/j.vetmic.2011.02.017. Epub Feb 23.

[152]Autheman D, Wyder M, Popoff M, D'Herde K, Christen S, Posthaus H. Clostridium perfringens beta-toxin induces necrostatin-inhibitable, calpain-dependent necrosis in primary porcine endothelial cells. PLoS One 2013;8:e64644. doi: 10.1371/journal.pone.0064644. Print 2013.

[153]Gibert M, Jolivet-Reynaud C, Popoff MR. Beta2 toxin, a novel toxin produced by Clostridium perfringens. Gene 1997;203:65-73.

[154]Herholz C, Miserez R, Nicolet J, Frey J, Popoff MR, Gibert M, et al. Prevalence of $\beta$ 2toxigenic Clostridium perfringens in horses with intestinal disorders. J Clin Microbiol 1999;37:358-61.

[155]Bueschel DM, Jost BH, Billington SJ, Trinh HT, Songer JG. Prevalence of cpb2, encoding beta2 toxin, in Clostridium perfringens field isolates: correlation of genotype with phenotype. Vet Microbiol 2003;94:121-9.

[156]Jost BH, Billington SJ, Trinh HT, Bueschel DM, Songer JG. Atypical cpb2 genes, encoding beta2-toxin in Clostridium perfringens isolates of nonporcine origin. Infect Immun 2005;73:652-6. 
[157]van Asten AJ, Nikolaou GN, Grone A. The occurrence of cpb2-toxigenic Clostridium perfringens and the possible role of the beta2-toxin in enteric disease of domestic animals, wild animals and humans. Vet J 2010;183:135-40.

[158]van Asten AJ, Allaart JG, Meeles AD, Gloudemans PW, Houwers DJ, Grone A. A new PCR followed by MboI digestion for the detection of all variants of the Clostridium perfringens cpb2 gene. Vet Microbiol 2008;127:412-6. Epub 2007 Sep 26.

[159]Vilei EM, Schlatter Y, Perreten V, Straub R, Popoff MR, Gibert M, et al. Antibioticinduced expression of a cryptic cpb2 gene in equine beta2-toxigenic Clostridium perfringens. Mol Microbiol 2005;57:1570-81.

[160]Waters M, Raju D, Garmory HS, Popoff MR, Sarker MR. Regulated expression of the beta2-toxin gene (cpb2) in Clostridium perfringens type a isolates from horses with gastrointestinal diseases. J Clin Microbiol 2005;43:4002-9.

[161]Bacciarini LN, Boerlin P, Straub R, Frey J, Grone A. Immunohistochemical localization of Clostridium perfringens beta2-toxin in the gastrointestinal tract of horses. Vet Pathol 2003;40:376-81.

[162]Lebrun M, Filee P, Mousset B, Desmecht D, Galleni M, Mainil JG, et al. The expression of Clostridium perfringens consensus beta2 toxin is associated with bovine enterotoxaemia syndrome. Vet Microbiol 2007;120:151-7.

[163]Harrison B, Raju D, Garmory HS, Brett MM, Titball RW, Sarker MR. Molecular characterization of Clostridium perfringens isolates from humans with sporadic diarrhea: evidence for transcriptional regulation of the beta2-toxin-encoding gene. Appl Environ Microbiol 2005;71:8362-70.

[164]Fisher DJ, Miyamoto K, Harrison B, Akimoto S, Sarker MR, McClane BA. Association of beta2 toxin production with Clostridium perfringens type A human gastrointestinal disease isolates carrying a plasmid enterotoxin gene. Mol Microbiol 2005;56:747-62.

[165]Waters M, Savoie A, Garmory HS, Bueschel D, Popoff MR, Songer JG, et al. Genotyping and phenotyping of beta2-toxigenic Clostridium perfringens fecal isolates associated with gastrointestinal diseases in piglets. J Clin Microbiol 2003;41:3584-91.

[166]Keyburn AL, Boyce JD, Vaz P, Bannam TL, Ford ME, Parker D, et al. NetB, a New Toxin That Is Associated with Avian Necrotic Enteritis Caused by Clostridium perfringens. PLoS Pathog 2008;4:e26.

[167]Keyburn AL, Bannam TL, Moore RJ, Rood JI. NetB, a Pore-Forming Toxin from Necrotic Enteritis Strains of Clostridium perfringens. Toxins (Basel) 2010;2:191327.

[168]Timbermont L, Haesebrouck F, Ducatelle R, Van Immerseel F. Necrotic enteritis in broilers: an updated review on the pathogenesis. Avian Pathol 2011;40:341-7. doi: 10.1080/03079457.2011.590967.

[169]Keyburn AL, Yan XX, Bannam TL, Van Immerseel F, Rood JI, Moore RJ. Association between avian necrotic enteritis and Clostridium perfringens strains expressing NetB toxin. Vet Res 2010;41:21. doi: 10.1051/vetres/2009069. Epub 2009 Nov 25. 
[170]Martin TG, Smyth JA. Prevalence of netB among some clinical isolates of Clostridium perfringens from animals in the United States. Vet Microbiol 2009;136:202-5.

[171]Shojadoost B, Vince AR, Prescott JF. The successful experimental induction of necrotic enteritis in chickens by Clostridium perfringens: a critical review. Vet Res 2012;43:74.:10.1186/297-9716-43-74.

[172]Cooper KK, Theoret JR, Stewart BA, Trinh HT, Glock RD, Songer JG. Virulence for chickens of Clostridium perfringens isolated from poultry and other sources. Anaerobe 2010;16:289-92. doi: 10.1016/j.anaerobe.2010.02.006. Epub Mar 1.

[173]Poulain B, Popoff MR, Molgo J. How do the botulinum neurotoxins block neurotransmitter release: from botulism to the molecular mechanism of action. Botulinum J 2008;1:14-87.

[174]Fischer A, Montal M. Molecular dissection of botulinum neurotoxin reveals interdomain chaperone function. Toxicon 2013;5:00033-0.

[175]Galloux M, Vitrac H, Montagner C, Raffestin S, Popoff MR, Chenal A, et al. Membrane Interaction of botulinum neurotoxin A translocation ( $\mathrm{T}$ ) domain. The belt region is a regulatory loop for membrane interaction. J Biol Chem 2008;283:27668-76.

[176] Montal M. Botulinum Neurotoxin: A Marvel of Protein Design. Annu Rev Biochem 2010;79:591-617.

[177]Jank T, Aktories K. Structure and mode of action of clostridial glucosylating toxins: the ABCD model. Trends Microbiol 2008;16:222-9.

[178]Barth H, Pfeifer G, Hofmann F, Maier E, Benz R, Aktories K. Low pH-induced formation of ion channels by Clostridium difficile toxin B in target cells. J Biol Chem 2001;276:10670-6.

[179]Qa'dan M, Spyres LM, Ballard JD. pH-induced conformational changes in Clostridium difficile toxin B. Infect Immun 2000;68:2470-4.

[180]Barth H, Aktories K, Popoff MR, Stiles BG. Binary bacterial toxins: biochemistry, biology, and applications of common Clostridium and Bacillus proteins. Microbiol Mol Biol Rev 2004;68:373-402.

[181]Stiles BG, Wigelsworth DJ, Popoff MR, Barth H. Clostridial binary toxins: iota and C2 family portraits. Front Cell Infect Microbiol 2011;1:11.

[182]Leppla SH. Bacillus anthracis toxins. In: Alouf JE, Popoff MR, editors. The Source Book of Bacterial Protein Toxins. $3^{\circ}$ ed. Amsterdam: Elsevier Academic Press; 2006, p. 323-47.

[183]Petosa C, Collier JR, Klimpel KR, Leppla SH, Liddington RC. Crystal structure of the anthrax toxin protective antigen. Nature (London) 1997;385:833-8.

[184]Simpson LL. Identification of the major steps in botulinum toxin action. Annu Rev Pharmacol Toxicol 2004;44:167-93.

[185]Simpson L. The life history of a botulinum toxin molecule. Toxicon 2013;68:4059.:10.1016/j.toxicon.2013.02.014. Epub Mar 18.

[186]Kelly CP, LaMont JT. Clostridium difficile--more difficult than ever. N Engl J Med 2008;359:1932-40. 
[187] Songer JG. Clostridial diseases in domestic animals. In: Dürre P, editor. Handbook on Clostridia. Boca Raton: CRC Press, Taylor and Francis Group; 2005, p. 527-42.

[188]Clark S. Sudden death in periparturient sheep associated with Clostridium sordellii. Vet Rec 2003;153:340.

[189]Lewis CJ, Naylor RD. Sudden death in sheep associated with Clostridium sordellii. Vet Rec 1998;142:417-21.

[190]Lewis CJ, Naylor R. Sudden death in lambs associated with Clostridium sordellii infection. Vet Rec 1996;138:262.

[191]Al-Mashat RR, Taylor DJ. Production of diarrhea and enteritic lesions in calves by the oral inoculation of pure cultures of Clostridium sordellii. Vet Rec 1983;112:141-6.

[192]Richards SM, Hunt BW. Clostridium sordellii in lambs. Vet Rec 1982;111:22.

[193]Al-Mashat RR, Taylor DJ. Clostridium sordellii in enteritis in an adult sheep. Vet Rec 1983;112:19.

[194]Popoff MR. Bacteriological examination in enterotoxaemia of sheep and lamb. Vet Rec 1984;114:324.

[195]Gerding DN, Johnson S, Rupnik M, Aktories K. binary toxin CDT: Mechanism, epidemiology, and potential clinical importance. Gut Microbes 2013;5:1.

[196]Moran Y, Fredman D, Szczesny P, Grynberg M, Technau U. Recurrent horizontal transfer of bacterial toxin genes to eukaryotes. Mol Biol Evol 2012;29:2223-30.

[197]Alouf JE, Billington SJ, Jost BH. Repertoire and general features of the family of cholesterol-dependent cytolysins. In: Alouf JE, Popoff MR, editors. The Comprehensive Sourcebook of Bacterial Protein Toxins. $3^{\circ}$ ed. Amsterdam: Elsevier, Academic Press; 2006, p. 643-58.

[198]Frey J, Johansson A, Burki S, Vilei EM, Redhead K. Cytotoxin CctA, a major virulence factor of Clostridium chauvoei conferring protective immunity against myonecrosis. Vaccine 2012;30:5500-5. doi: 10.1016/j.vaccine.2012.06.050. Epub Jun 27.

[199]Vilei EM, Johansson A, Schlatter Y, Redhead K, Frey J. Genetic and functional characterization of the NanA sialidase from Clostridium chauvoei. Vet Res 2011;42:2.:10.1186/297-9716-42-2.

[200]Basak A, Popoff MR, Titball RW, Cole AR. Clostridium perfringens $\varepsilon$-toxin. In: Alouf JE, Popoff MR, editors. The Comprehensive Sourcebook of Bacterial Protein Toxins. $3^{\circ}$ ed. Amsterdam: Elsevier, Academic Press; 2006, p. 631-42.

[201]Brynestad S, Granum PE. Clostridium perfringens and foodborne infections. Int J Food Microbiol 2002;74:195-202.

[202]Smedley JG, 3rd, Fisher DJ, Sayeed S, Chakrabarti G, McClane BA. The enteric toxins of Clostridium perfringens. Rev Physiol Biochem Pharmacol 2004;152:183-204.

[203]Chew SS, Lubowski DZ. Clostridium septicum and malignancy. ANZ J Surg 2001;71:647-9. 
[204]Kornbluth AA, Danzig JB, Bernstein LH. Clostridium septicum infection and associated malignancy report of two cases and review of the litterature. Medicine (Baltimore) 1989;68:30-7.

[205]Borriello SP, Carman RJ. Clostridial diseases in the gastrointestinal tract in animals. In: Borriello SP, editor. Clostridia in gastrointestinal disease. Boca Raton, Fla.: CRC Press; 1985, p. 195-221.

[206]Schamber GJ, Berg IE, Molesworth JR. Braxy or Bradsot-like Abomastitis Caused by Clostridium septicum in a Calf. Can Vet J 1986;27:194.

[207]Jolivet-Reynaud C, Launay JM, Alouf JE. Damaging effects of Clostridium perfringens delta toxin on blood platelets and their relevance to ganglioside GM2. Arch Biochem Biophys 1988;262:59-66.

[208]Lawrence G. The pathogenesis of pig-bel in Papua New Guinea. 1979. P N G Med J 2005;48:39-49.

[209]Hatheway CL. Toxigenic clostridia. Clin Microbiol Rev 1990;3:66-98.

[210]Rossjohn J, Buckley JT, Hazes B, Murzin AG, Read RJ, Parker MW. Aerolysin and pertussis toxin share a common receptor-binding domain. Embo J 1997;16:342634.

[211]Chakraborty T, Schmid A, Notermans S, Benz R. Aerolysin of Aeromonas sobria: evidence for the formation of ion-permeable channels and comparison with alphatoxin of Staphylococcus aureus. Infect Immun 1990;58:2127-32.

[212]Petit L, Maier E, Gibert M, Popoff MR, Benz R. Clostridium perfringens epsilon-toxin induces a rapid change in cell membrane permeability to ions and forms channels in artificial lipid bilayers. J Biol Chem 2001;276:15736-40.

[213]Hardy SP, Denmead M, Parekh N, Granum PE. Cationic currents induced by Clostridium perfringens type A enterotoxin in human intestinal CaCO-2 cells. J Med Microbiol 1999;48:235-43.

[214]Blaustein RO, Koehler TM, Collier RJ, Finkelstein A. Anthrax toxin: channel-forming activity of protective antigen in planar phospholipid bilayers. Proc Natl Acad Sci U S A 1989;86:2209-13.

[215]Finkelstein A. The channel formed in planar lipid bilayers by the protective antigen component of anthrax toxin. Toxicology 1994;87:29-41.

[216]Knapp 0, Benz R, Gibert M, Marvaud JC, Popoff MR. Interaction of Clostridium perfringens iota-toxin with lipid bilayer membranes. J Biol Chem 2002;277:614352.

[217]Blöcker D, Pohlmann K, Haug G, Bachmeyer C, Benz R, Aktories K, et al. Clostridium botulinum $\mathrm{C} 2$ Toxin: low $\mathrm{pH}$-induced pore formation is required for translocation of the enzyme component C2I into the cytosol of host cells. J Biol Chem 2003;278:37360-7.

[218]Gill DM. Bacterial toxins: a table of lethal amounts. Microbiol Rev 1982;46:86-94. 


\section{FIGURE LEGENDS}

Figure 1. Examples of bacterial $\alpha$-pore-forming toxins (PFT). A) Colicins retain a conserved structural organization consisting of a translocation domain, receptor-binding domain, and catalytic or pore-forming domain, rich in $\alpha$-helices. Colicin E3 (pdb 1JCH) is shown as an example. B) The C-terminal pore-forming domain of colicin A (pdb $1 \mathrm{COL}$ ) consists of a bundle of $10 \alpha$-helices. The hydrophobic H8 and H9 $\alpha$-helices are in magenta. C) Diphtheria toxin (pdb 1DDT) consists of a N-terminal catalytic domain (blue), translocation domain (red), and receptor-binding domain (green). Hydrophobic H8 and H9 $\alpha$-helices are in magenta. D) Escherichia coli hemolysin E, monoer and dodecamer assembled in a (pdb 1QOY). Figures were produced with the program MacPyMOL.

Figure 2. General model of $\beta$-pore-forming toxin ( $\beta$-PFT) mechanism of action. The secreted soluble monomers recognize specific cell surface receptor(s), assemble, oligomerize, unfold amphipatic $\beta$-hairpin(s), which form a prepore and then insert into the membrane.

Figure 3. Structure of Perfringolysin (PFO) and pore formation. A) Structural PFO organization in 4 domains (pdb 1PFO). B) View of domain D3 with the transmembrane hairpins $(\mathrm{TMH})$ in the helical conformation and the $\beta 5$ strand bended on $\beta 4$ strand. $\mathrm{C}$ ) Schematic representation of two assembled PFO monomers; Binding of domain D4 to cholesterol triggers a conformational change relayed by the undecapeptide segment to domain D3 and leading to displacement of $\beta 5$ strand from $\beta 4$ strand thus allowing assembly of two monomers and unfolding of $\alpha$-helices of domain D3 in two amphipatic $\beta$-hairpins. D) Schematic representation of a PFO pore inserted into the lipid bilayer. Subsequently to a vertical collapse of oligomerized PFO molecules, the prepore inserts into the lipid bilayer. Figures were produced with the program MacPyMOL.

Figure 4. Main steps in the pathogenesis of clostridial gangrenes.

Figure 5. Structure of aerolysin and related clostridial $\beta$-PFTs: $C$. perfringens epsilon toxin and $C$. perfringens enterotoxin. (A) aerolysin monomer (Pdb, 1PRE) and schematic representation of the pore formation according to [101]. Binding receptor sites are localized in domains 1 and 2. Upon binding to their receptor, monomers heptamerize and form a 
prepore showing an inverted mushroom shape, of which domains 1 and 2 constitute the cap. Then, the stalk, which is constituted of domains 3 and 4, rotates and completely collapses, and the $\beta$-barrel extends in the opposite orientation to that of the stalk in the prepore conformation. Two monomers (red and blue) are shown in the heptameric structure. Structures of (B) C. perfringens epsilon toxin monomer (Pdb, 1UYJ), and (C) C. perfringens enterotoxin (CPE) Pdb, 2XH6, 2QUO). The receptor binding domains are in green, the domains containing the pre-stem loop (red) are in yellow, and the domains, which contain the propeptide and which are involved in the control of oligomerization, are in blue. Figures were produced with the program MacPyMOL.

Figure 6. Structure of Staphylococcus aureus alpha hemolysin (Pdb 7AHL, 4IDJ), and related clostridial $\beta$-PFTs: $C$. perfringens delta toxin (Pdb, 2YGT), and NetB (410N, 4H56). The receptor binding domain (rim) is in green, the domain (stem) which unfolds in amphipatic $\beta$ hairpin in the open conformation and forms the $\beta$-barrel is in red, and the domain forming the cap of the mushroom shaped oligomer is in blue. Figures were produced with the program MacPyMOL.

Figure 7. Pore forming domains of clostridial intracellularly active toxins. (A) Botulinum neurotoxin type A (BoNT/A) (Pdb, 3BTA) is a single chain protein toxin which contains two long $\alpha$-helices in its translocation domain located in the $\mathrm{N}$-terminal half of the heavy chain $\left(\mathrm{H}_{\mathrm{N}}\right)$ and which mediates the translocation into the cytosol of the catalytic light chain (L). (B) Binding components of the clostridial binary toxins such as $\mathrm{C} 2-\mathrm{II}$ (Pdb, 2J42), the binding component of C. botulinum $\mathrm{C} 2$ toxin, are structurally related to the protective antigen (PA) (Pdb, 3QBB) of Bacillus anthracis toxins, and show a common structural organization with that of the pore-forming toxin, PFO. However, domain 2 of PA or C2-II contains only one $\beta$ hairpin forming the $\beta$-barrel, instead of two trans membrane hairpins in domain 3 of PFO. (C) PA prepore bound to receptor. PA heptamer with each monomer bound to the domain VWA of the receptor CMG2 (Pdb, 1TZN). One monomer is coloured in 4 domains and one receptor molecule is in brown. In the prepore state the $\beta$-barrel is not yet formed. Figures were produced with the program MacPyMOL.

Figure 8. Hypothetical evolutionary lineages of bacterial pore-forming toxins (PFTs) toxin genes. PFTs likely derive from a common ancestor, probably a transmembrane 
protein ancestor. Except clostridial single chain protein toxins, which use $\alpha$-helices to form a pore, clostridial PFTs belong to the $\beta$-PFT family. The cholesterol dependent cytolysins (CDC) form large pores, whereas the heptameric $\beta$-PFTs (staphylococcal $\alpha$ hemolysin family and aerolysin family) induce small pores. Interestingly, binary toxins produced by certain Clostridium and Bacillus, seem to have emerged from a convergent or cross evolution between $\beta$-PFTs and toxins having an enzymatic activity. Binding components, which are structurally related to $\beta$-PFTs of the CDC family and retain similarity with aerolysin toxins, have evolved to specifically internalize an enzymatic protein into cell trough a pore-forming mechanism. The single chain protein intracellularly active toxins probably derive from an enzyme ancestor and have acquired by gene duplication/modification or by fusion with other gene precursors new functional domains mediating the transport into the cytosol of target cells. The single chain protein intracellularly active toxins use $\alpha$-helices for the translocation of the enzymatic domain across the endosomal membrane. 


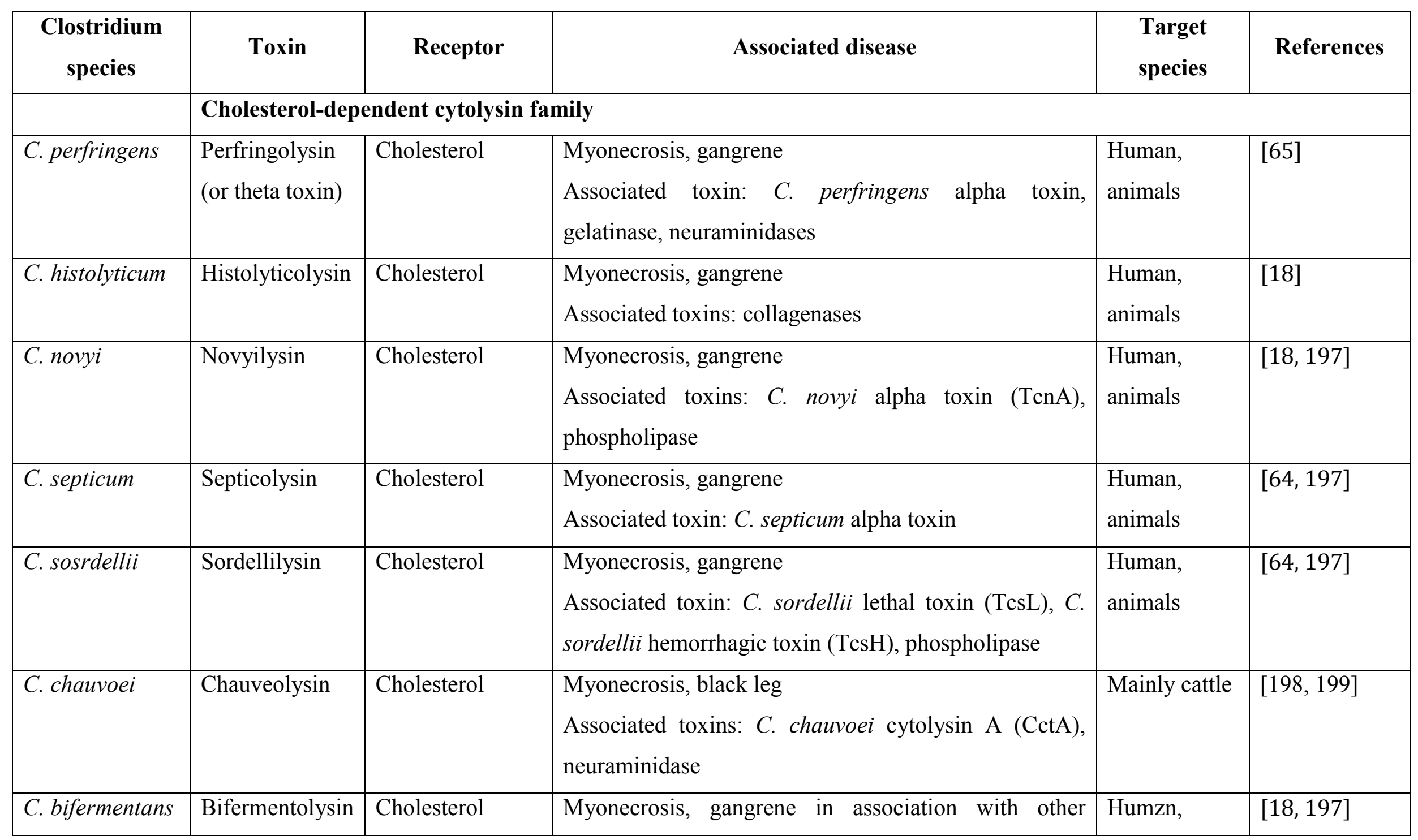




\begin{tabular}{|c|c|c|c|c|c|}
\hline & & & $\begin{array}{l}\text { agents of gangrene } \\
\text { Associated toxin: phospholipase }\end{array}$ & animals & \\
\hline C. botulinum & Botulinolysin & Cholesterol & $\begin{array}{l}\text { Botulism } \\
\text { Associated toxin: botulinum neurotoxin }\end{array}$ & $\begin{array}{l}\text { Human, } \\
\text { animals }\end{array}$ & {$[70,71]$} \\
\hline C. tetani & Tetanolysin & Cholesterol & $\begin{array}{l}\text { Tetanus } \\
\text { Associated toxin: tetanus neurotoxin }\end{array}$ & $\begin{array}{l}\text { Human, } \\
\text { animals }\end{array}$ & [69] \\
\hline C. perfringens & Epsilon toxin & $\begin{array}{l}\text { MLA } \\
\text { HAVCR1? }\end{array}$ & Enterotoxemia & $\begin{array}{l}\text { Sheep, goat, } \\
\text { cattle }\end{array}$ & {$[106,200]$} \\
\hline C. perfringens & Enterotoxin & Claudin & $\begin{array}{l}\text { Food borne poisoning, sporadic diarrhea } \\
\text { Diarrhea }\end{array}$ & $\begin{array}{l}\text { Human } \\
\text { Pig }\end{array}$ & $\begin{array}{l}{[115,122,} \\
201,202]\end{array}$ \\
\hline & \multicolumn{5}{|c|}{ Staphylococcus aureus alpha-toxin family } \\
\hline C. perfringens & Delta toxin & GM2 & $?$ & $\begin{array}{l}\text { Human? } \\
\text { animals? }\end{array}$ & {$[126,207]$} \\
\hline C. perfringens & NetB & $?$ & Necrotizing enteritis & Chickens & $\begin{array}{l}{[166, \quad 168-} \\
171]\end{array}$ \\
\hline C. perfringens & Beta toxin & $?$ & Necrotizing enteritis (Pig Bel) & Human & {$[208]$} \\
\hline
\end{tabular}




\begin{tabular}{|l|l|l|l|l|l|}
\hline & & & $\begin{array}{l}\text { Necrotizing enteritis } \\
\text { Enterotoxemia (struck) }\end{array}$ & $\begin{array}{l}\text { Piglet, calve } \\
\text { Sheep }\end{array}$ & $\begin{array}{l}\text { 209] } \\
\text { C. perfringens }\end{array}$ \\
& Beta2 toxin & $?$ & $\begin{array}{l}\text { Necrotizing enteritis } \\
\text { Typhlocolitis }\end{array}$ & $\begin{array}{l}\text { Piglet } \\
\text { Horse }\end{array}$ & $\begin{array}{l}{[153,} \\
156,157] .\end{array}$ \\
\hline C. chauvoei & CctA & $?$ & Gangrene, black leg & cattle & {$[198]$} \\
\hline
\end{tabular}

Table 1. Clostridial pore-forming toxins, receptor, and associated pathology. 


\begin{tabular}{|c|c|c|c|c|c|c|}
\hline Toxin & $\begin{array}{l}\text { Pore size } \\
\quad \text { (nm) }\end{array}$ & $\begin{array}{c}\text { Number of } \\
\text { monomers } \\
\text { forming the } \\
\text { pore }\end{array}$ & $\begin{array}{c}\text { Channel } \\
\text { conductance }(\mathrm{pS}) \\
\text { In } 1 \mathrm{M} \mathrm{KCl}\end{array}$ & Pore selectivity & $\begin{array}{c}\text { Toxicity } \\
\text { Mouse lethal } \\
\text { dose }^{5} \mu \mathrm{g} / \mathrm{kg} \text { by } \\
\text { intraperitoneal } \\
\text { route }\end{array}$ & References \\
\hline Perfringolysin & $25-45$ & $40-50$ & $4000-6000^{\&}$ & & $13-16^{2}$ & {$[30,210]$} \\
\hline Aerolysin & $0.7-1$ & 7 & 650 & anionic & 10 & {$[211]$} \\
\hline Epsilon toxin & 1 & 7 & 550 & anionic & 0.07 & [212] \\
\hline $\mathrm{CPE}$ & $0.6-0.7$ & $7 ?$ & $565^{3}$ & cationic & 80 & [213] \\
\hline $\begin{array}{l}\text { S. aureus } \alpha- \\
\text { hemolysin }\end{array}$ & $0.8-1$ & $7(6$ to 8$)$ & 820 & anionic & $0.04-0.06^{2}$ & [211] \\
\hline NetB & $?$ & 7 & $325^{3}$ & cationic & & {$[124]$} \\
\hline Delta toxin & 4 & $7 ?$ & 130 & anionic & $5^{2}$ & [126] \\
\hline Beta toxin & 1.2 & $7 ?$ & $\begin{array}{c}550 \\
60-110^{4}\end{array}$ & cationic & $<0.4$ & {$[126,141]$} \\
\hline $\begin{array}{l}\text { C2 toxin binding } \\
\text { component }(\mathrm{C} 2- \\
\text { II) }\end{array}$ & $1-2$ & 7 & 150 & cationic & & {$[216,217]$} \\
\hline
\end{tabular}

\footnotetext{
${ }^{1}$ in $0.2 \mathrm{M} \mathrm{NaCl}$

${ }^{2}$ intravenous administration

${ }^{3}$ in $\mathrm{O} .1 \mathrm{M} \mathrm{KCl}$

${ }^{4}$ in $0.1 \mathrm{M} \mathrm{NaCl}$

5 according to [218]
} 
Table 2. Main properties of channel activity of clostridial and related pore-forming toxins. 

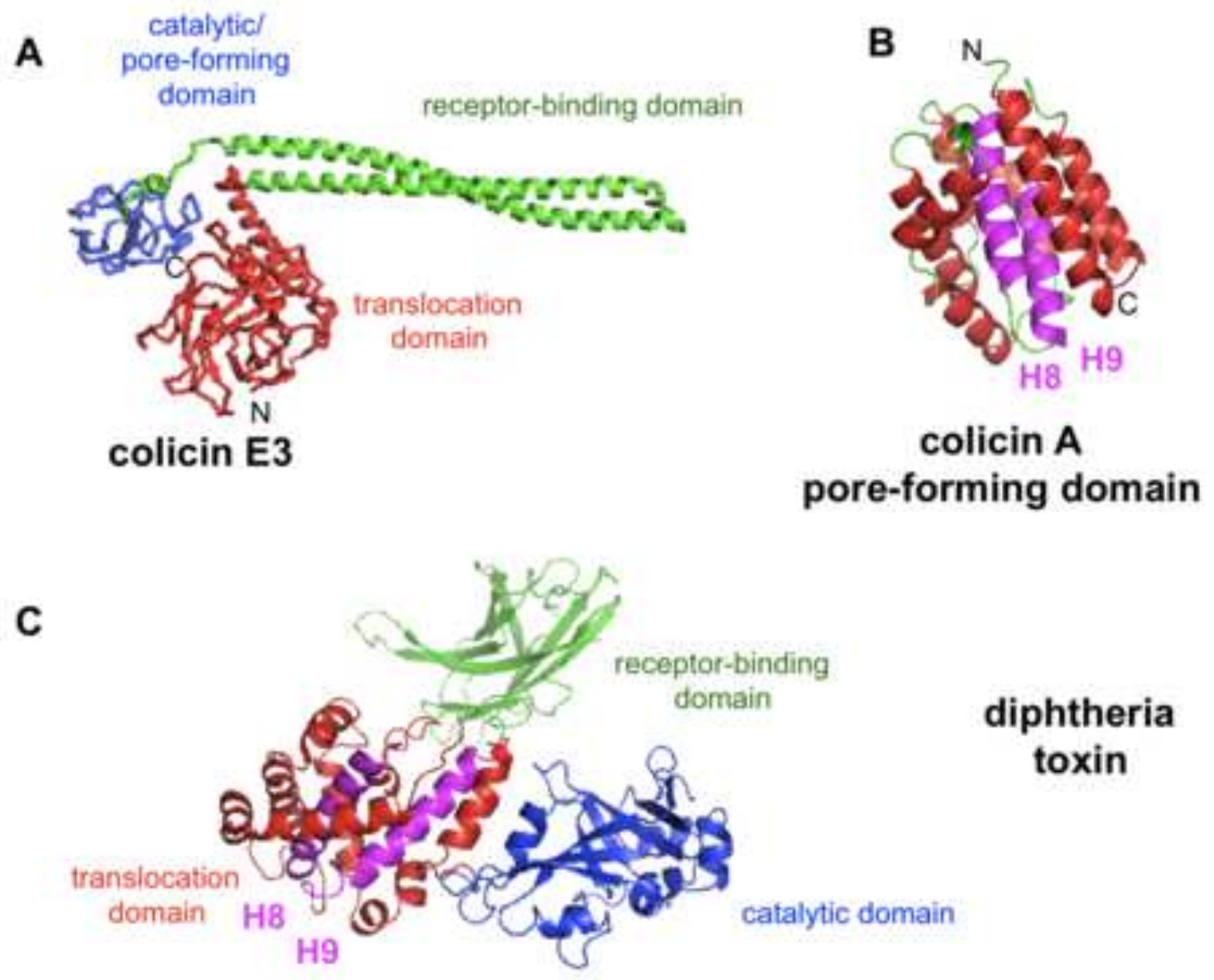

D

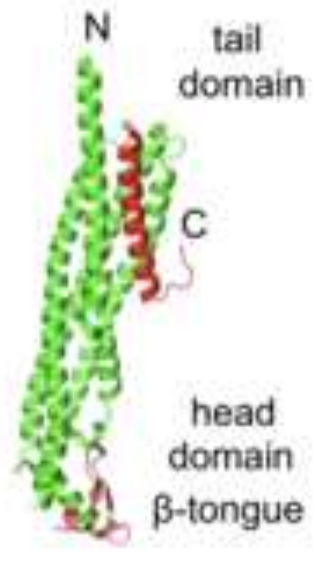

Monomer
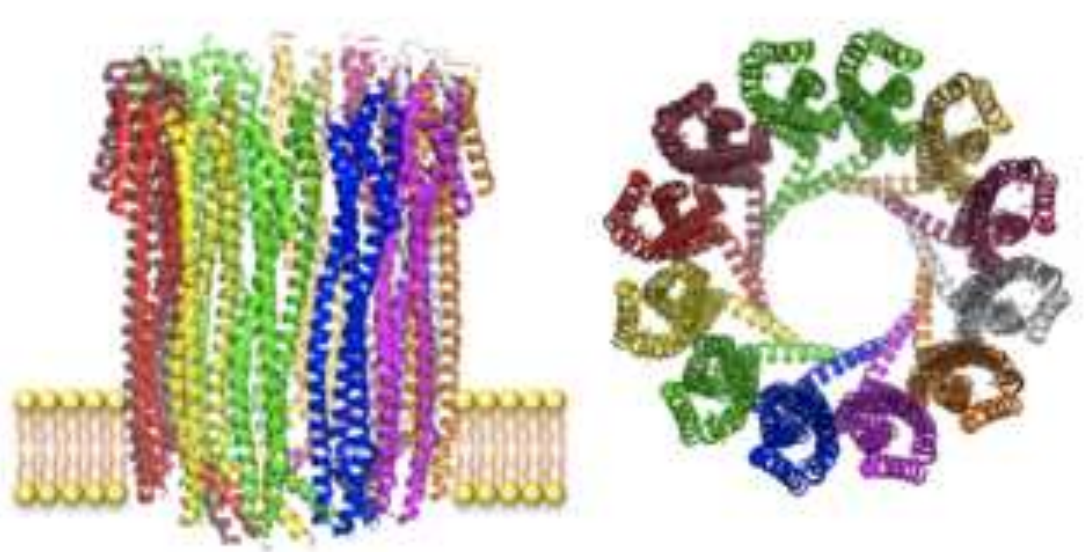

dodecameric pore

\section{Hemolysin E}

Figure 1 
Figure

Click here to download high resolution image

soluble

monomer

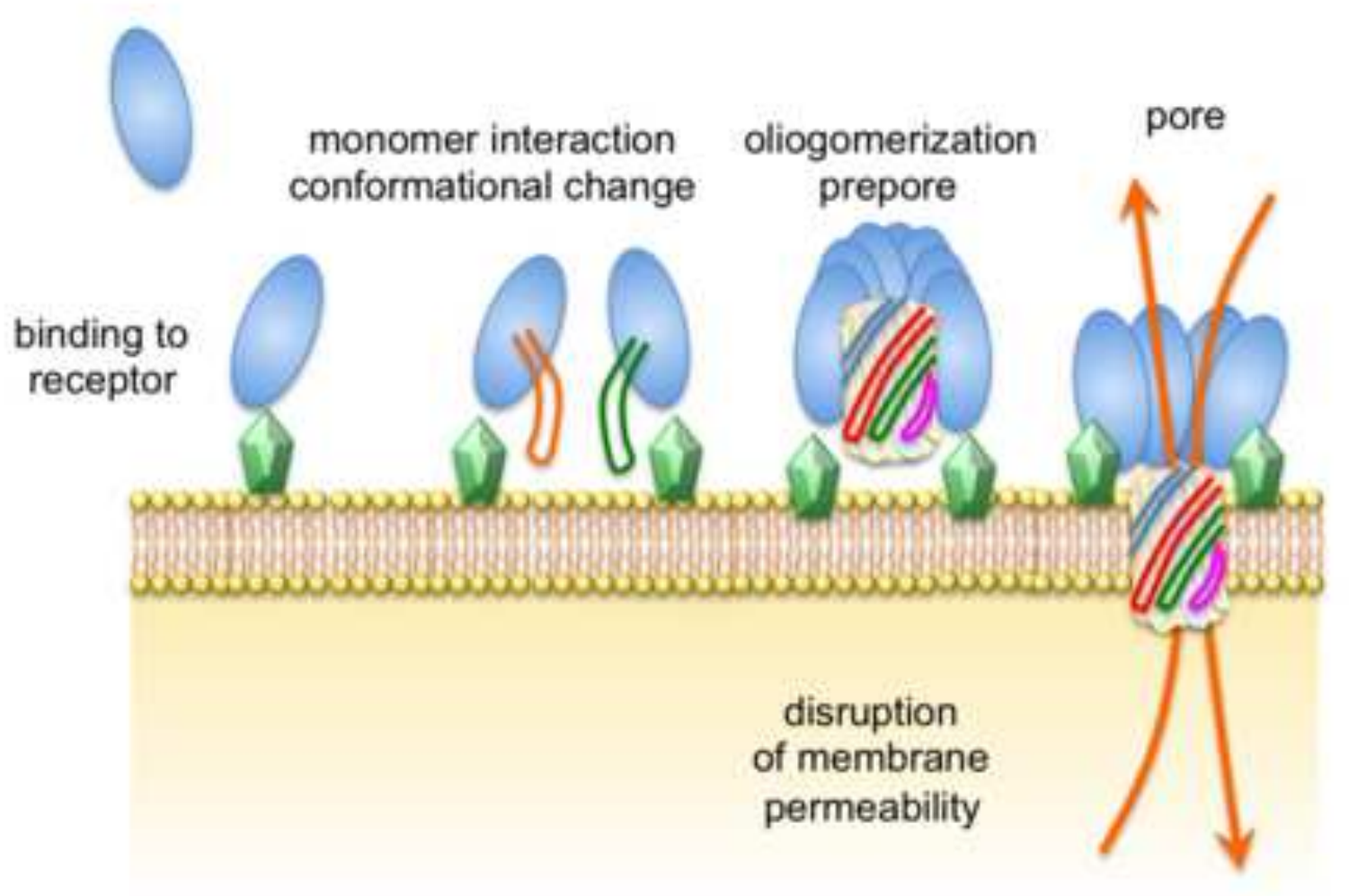

Figure 2 


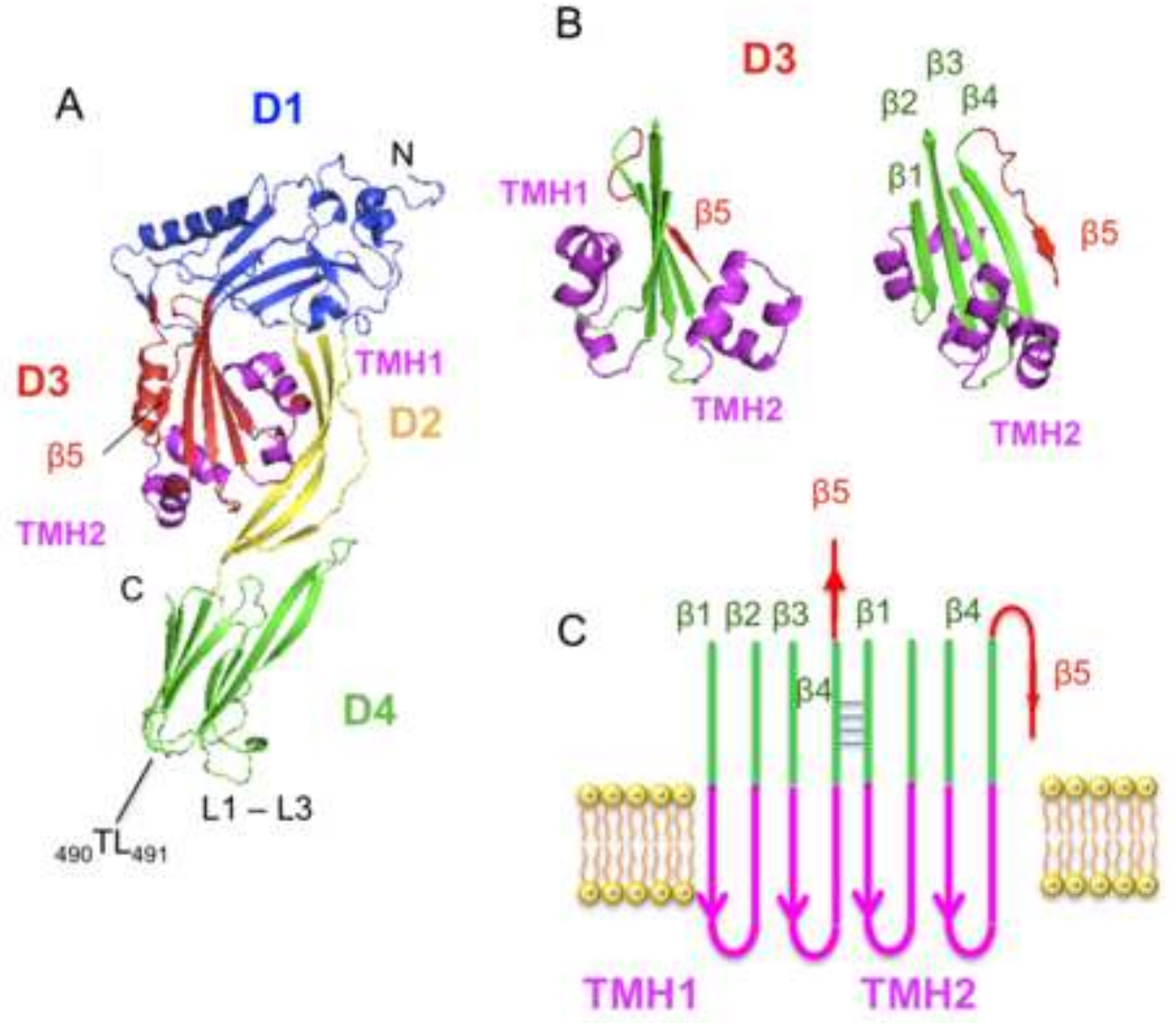

Two amphipatic $\beta$-hairpins from each monomer assemble to form the $\beta$-barrel

CDCs including PFO form large pores 35-50 monomers (25-30 $\mathrm{nm}$ diameter)

\section{Figure 3}

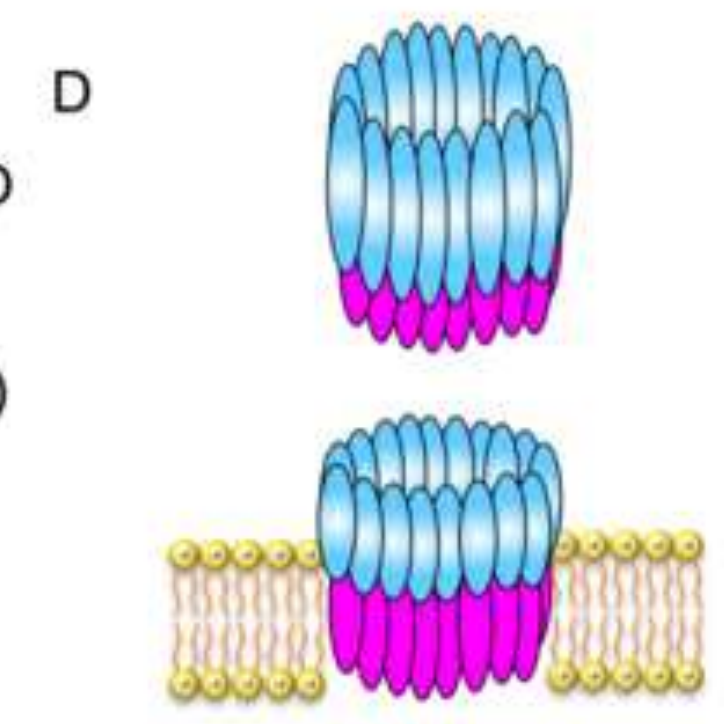




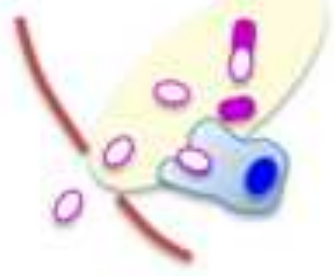

traumatic lesion

- interruption of blood supply, hypoxia

- drop in oxydation reduction potential

- release of nutrients from injured cells

spore germination

- bacterial growth in anaerobic conditions

- resistance to macrophages

- tegument or mucosa effraction

- spore contamination

toxins at sublethal concentration

- inhibition of neutrophil/macrophage migration

- inhibition of phagocytosis

- leucocyte/platelet aggregation

microvessel obstruction

- endothelial cell injury

- ischemia

TNF, IL1, IL6, ...

clostridial proliferation

$\mathrm{pH} \mathbf{y}$

redox potential $\mathbf{y}$

toxin and gas production
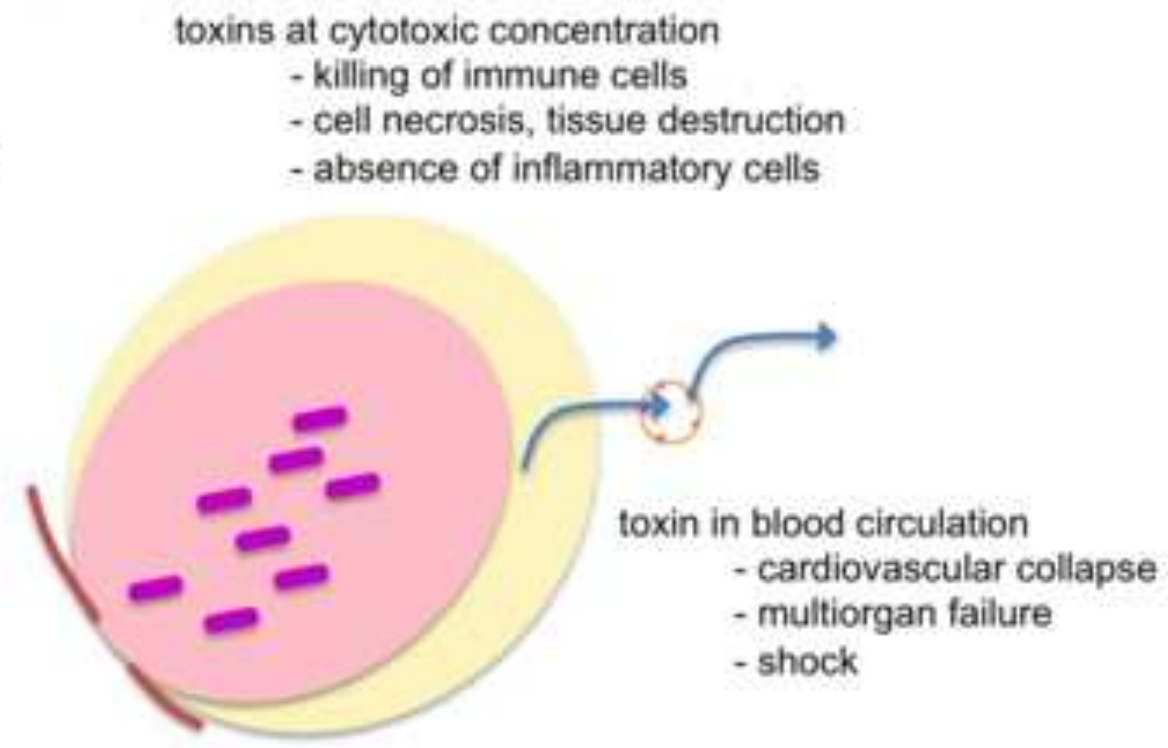

local clostridial proliferation

conious toxin production

local extension of the lesions

\section{Figure 4}




\section{Figure}

Click here to download high resolution image

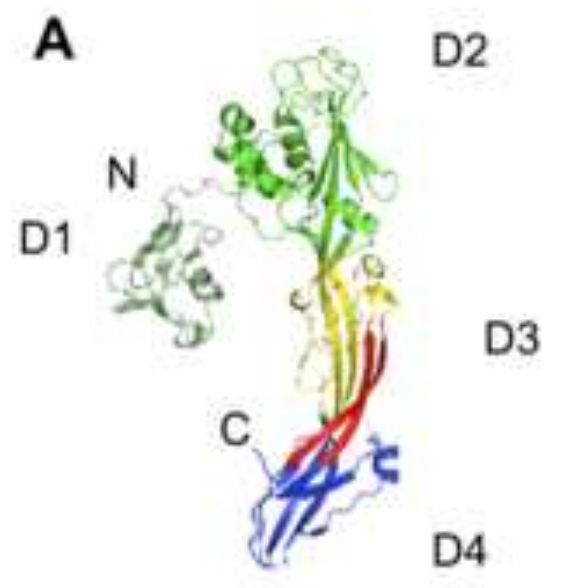

\section{Aerolysin}

B

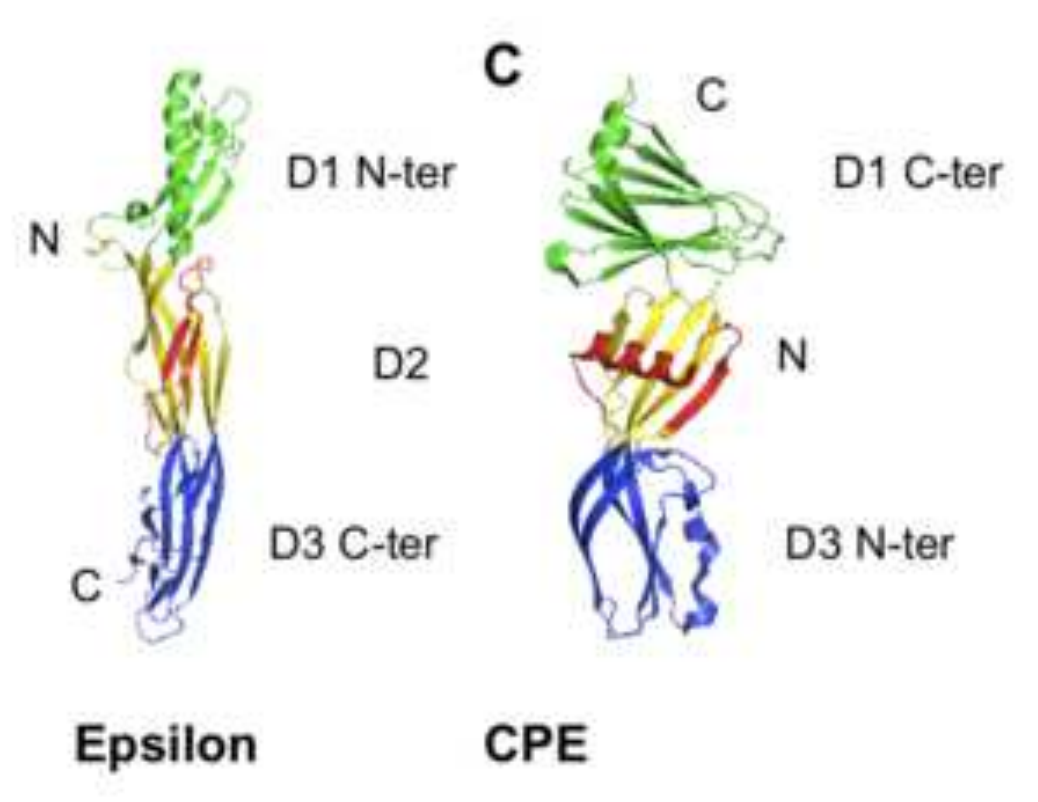

Figure 5

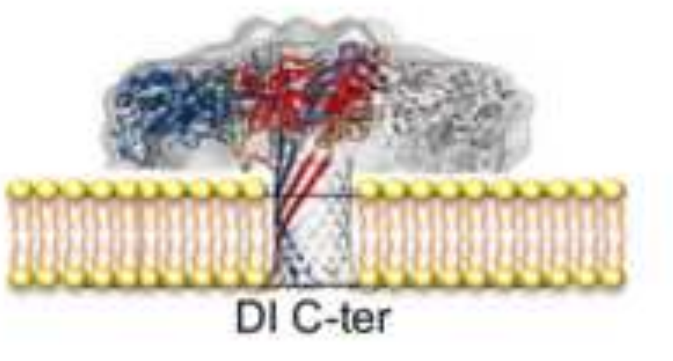


A

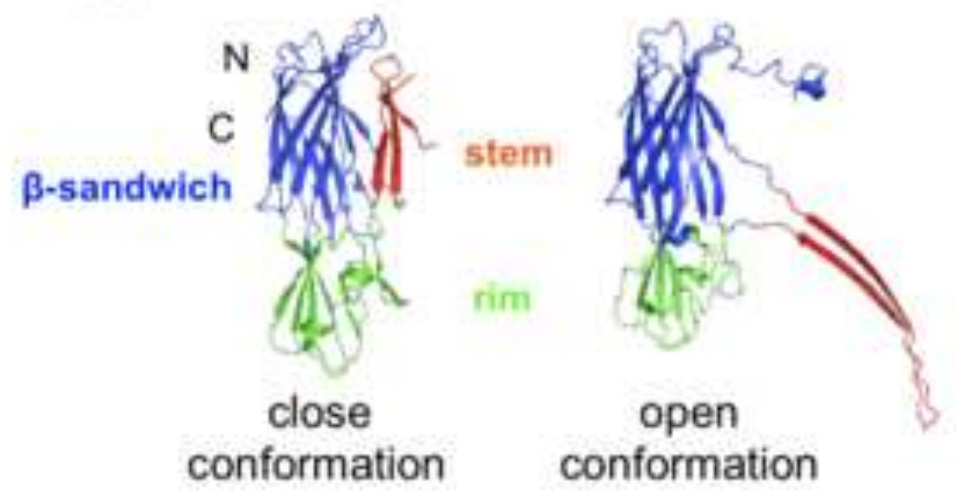

\section{Staphylococcus aureus alpha hemolysin}

B

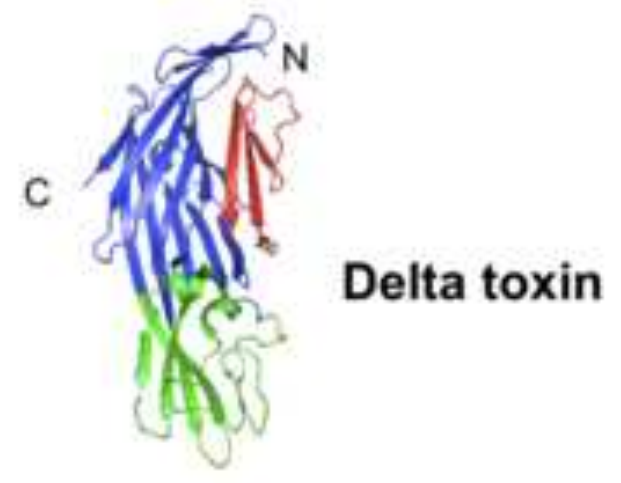

C

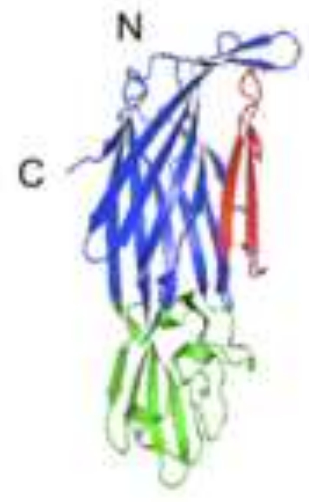

close conformation
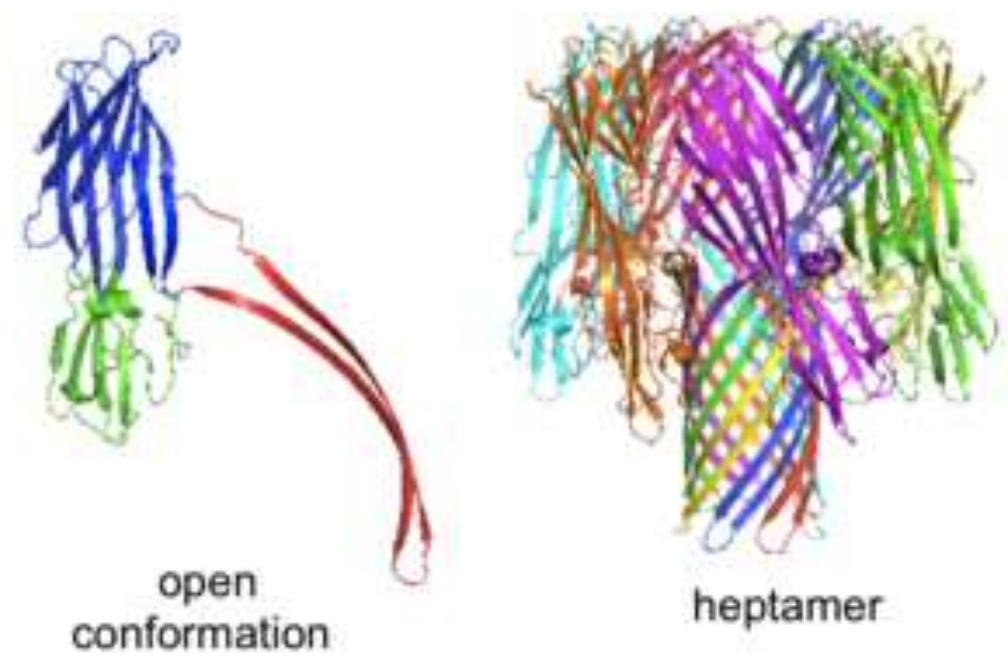

NetB

Figure 6 
Click here to download high resolution image
Clice

A

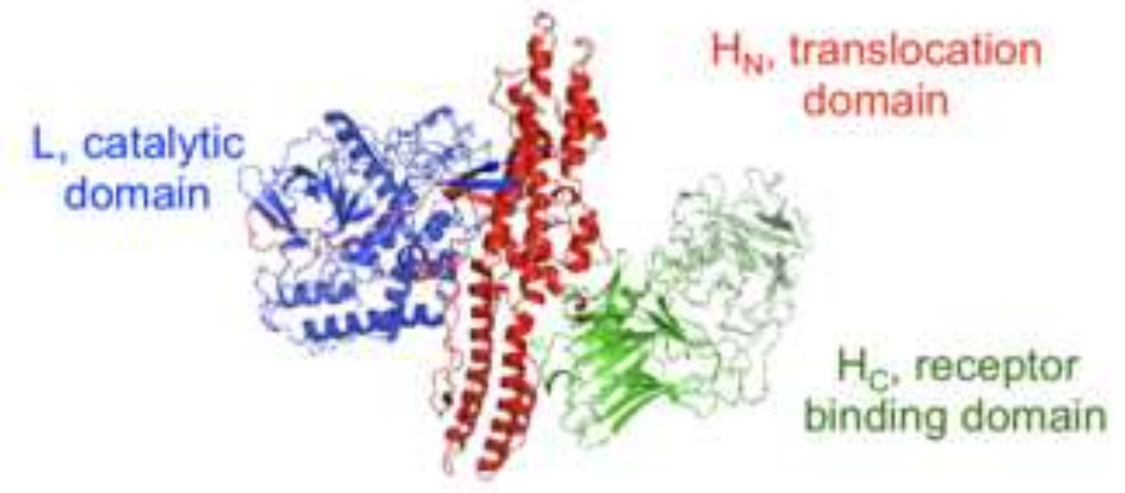

\section{BoNT/A}

B
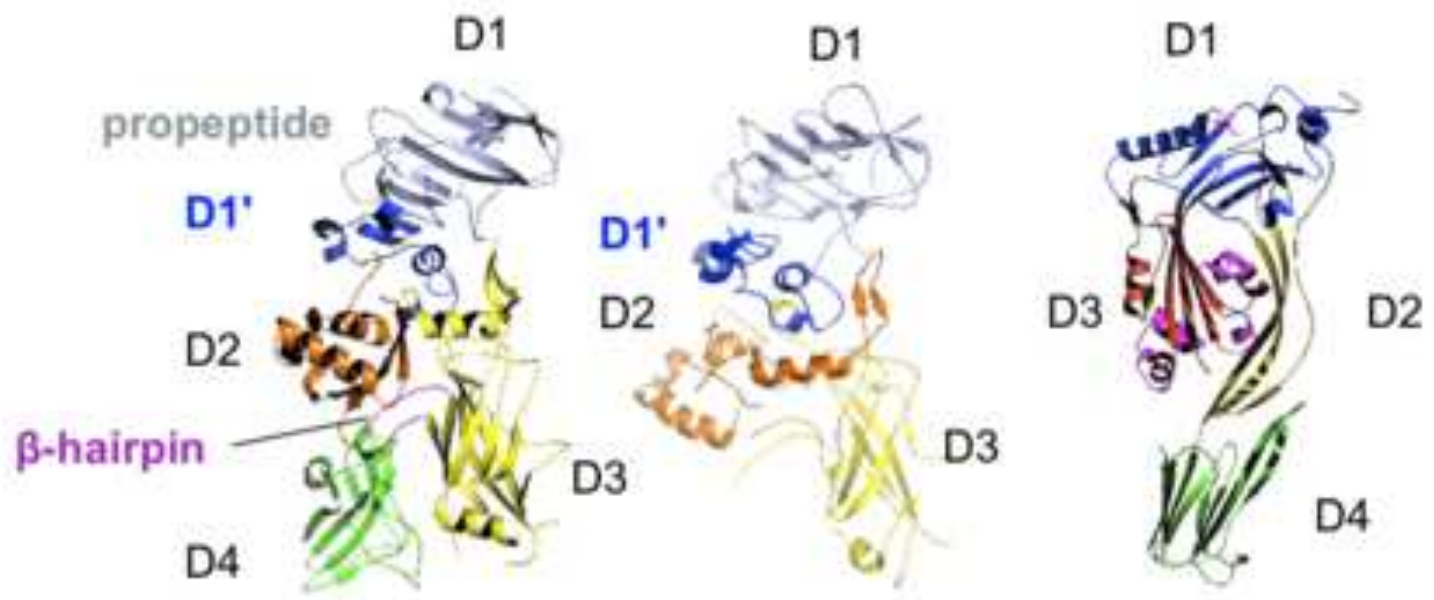

PA

C2-II partial

(D4 omitted)

PFO

Figure 7 
Figure

C
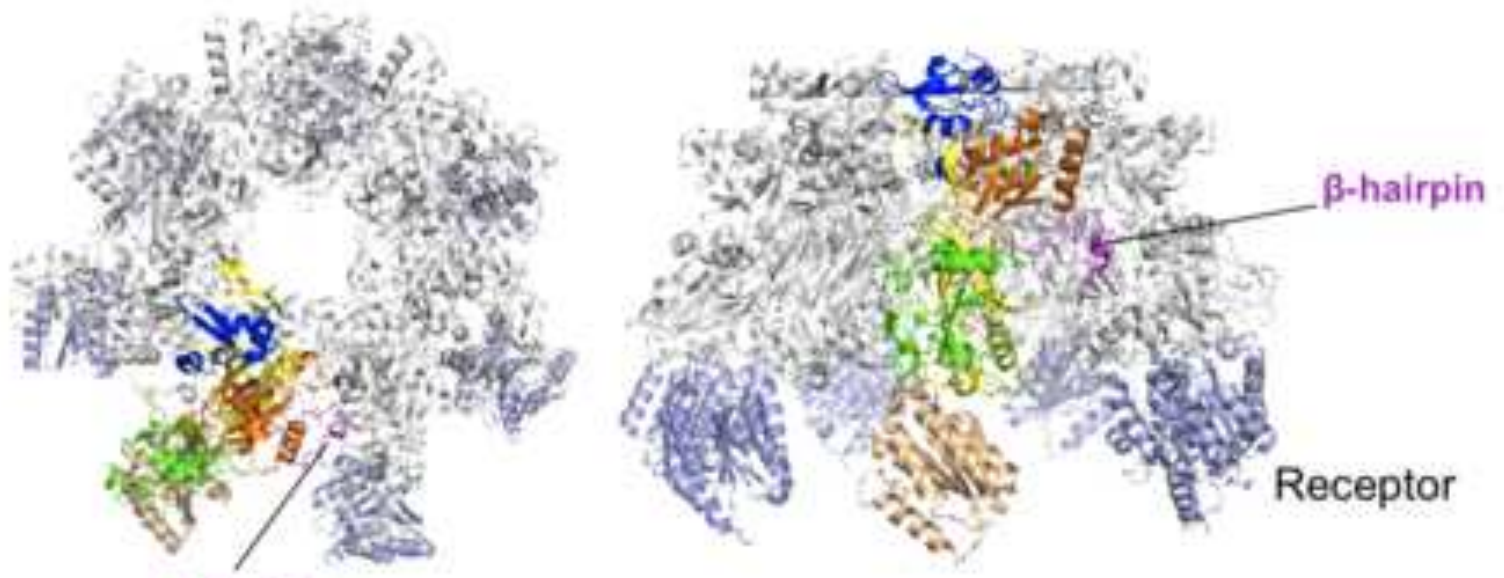

$\beta$-hairpin

\section{PA heptamer}

Figure 7 (followed) 


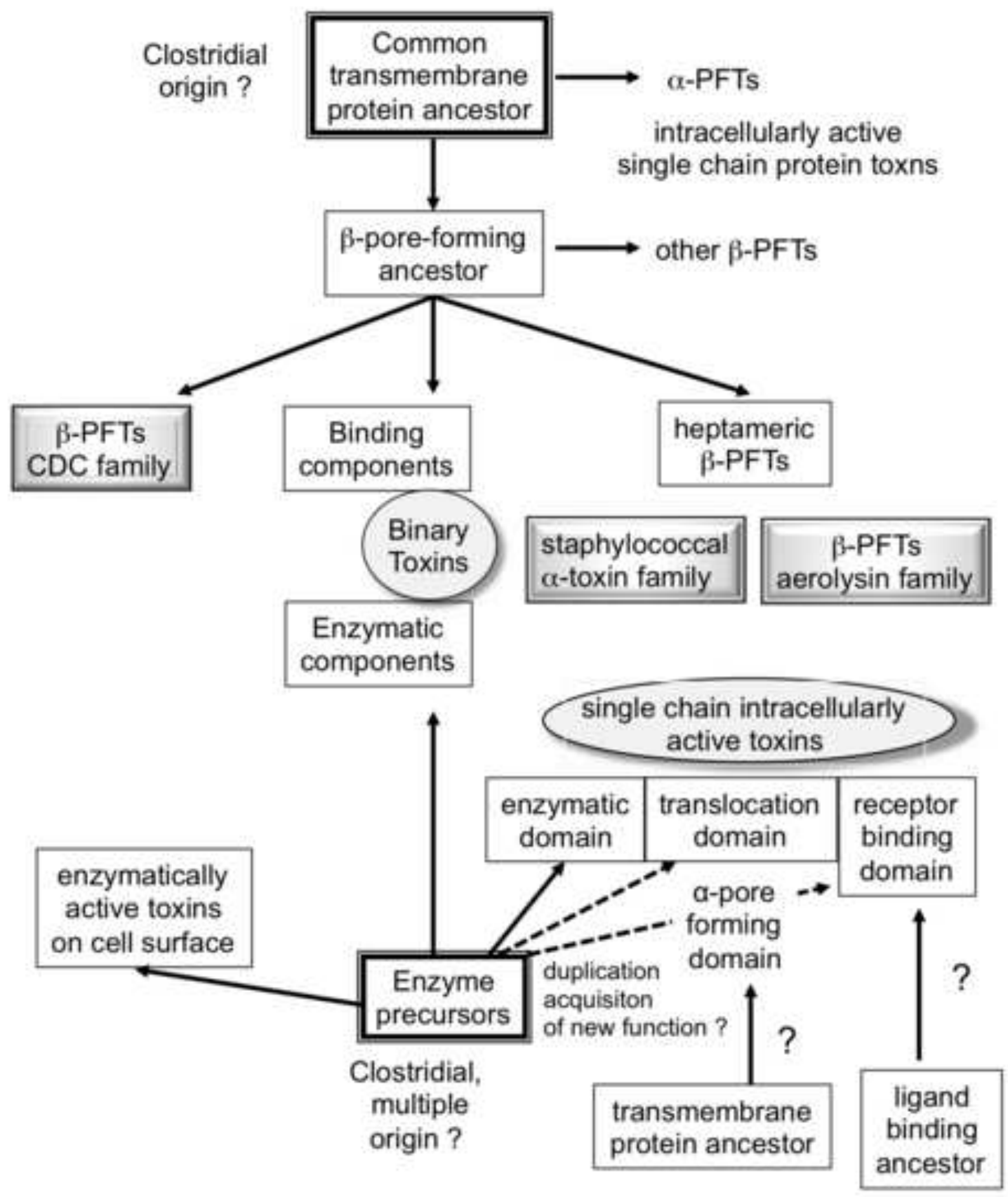

Figure 8 